\title{
Disentangling the Fiscal Effects of Local Constitutions
}

\author{
Jarosław Kantorowicz ${ }^{\mathrm{b}, 2}$, Monika Köppl-Turyna ${ }^{\mathrm{a}, 1, *}$ \\ a Agenda Austria, Türkenstrasse 25, 1090 Vienna, Austria \\ ${ }^{b}$ Institute of Security and Global Affairs $\&$ Department of Economics, Leiden University
}

\begin{abstract}
We apply a regression discontinuity design to verify how constitutional rules, such as electoral systems, shape budget revenues at the subnational governmental level. We take advantage of a natural experiment involving an institutional reform at the local level in Poland. The reform introduced two electoral rules, which changed according to an exogenous population threshold: smaller municipalities used majoritarian elections and larger municipalities used proportional elections. While intergovernmental grants increased in both small and large municipalities, they increased less in municipalities with majoritarian elections compared to jurisdictions with proportional representation. This has further implications regarding the level of property taxes and vertical fiscal imbalance. The jurisdictions with proportional electoral systems had lower revenues from property taxes and higher vertical fiscal imbalance than jurisdictions with majoritarian systems. We show that this effect works through the alignment channel, which is driven by the political alignment of mayors with parties in the central government. This is more prevalent in proportional election scenarios. We also demonstrate that these effects are more pronounced in the period after 2002, when direct elections of mayors were introduced.
\end{abstract}

This article is published in the Journal of Economic Behavior \& Organization. Cite as: Jaroslaw Kantorowicz, Monika Koeppl-Turyna, Disentangling the fiscal effects of local constitutions, Journal of Economic Behavior \& Organization, Volume 163, 2019, Pages 63-87, ISSN 0167-2681, https://doi.org/10.1016/j.jebo.2019.05.013

JEL classification: D72; D78; H72; R50

Keywords: electoral rules; forms of government; fiscal policy; local government

\footnotetext{
*Corresponding author: Phone: +43660 6988114

${ }^{1}$ Email: monika.koeppl-turyna@agenda-austria.at

${ }^{2}$ Email: j.j.kantorowicz@fgga.leidenuniv.nl
} 


\section{Introduction}

There is a strong theoretical case, and growing empirical evidence from within-country studies, suggesting that earned, (e.g., local taxes) and unearned, (e.g., intergovernmental transfers) budget revenues affect public goods provision differently. The intuitive argument is that (local) taxes, in contrast to intergovernmental transfers, raise fiscal awareness and hence encourage the monitoring of local government service costs by taxpayers, resulting in more effective provision of public goods, more accountability and more appeals to antiincumbent policy actions (see, for instance, Oates, 2001; Martinez, 2014; Gadenne, 2017). Empirical evidence supporting this claim can be found, inter alia, in Borge and Rattso (2008), Paler (2013), Martinez (2014) and Gadenne (2017). In this paper, we take a step back and ask what determines the size and composition of budget revenues at the local level. In other words, what affects the budgetary mix of local taxation and intergovernmental transfers, with the emphasis on the latter. We study this question through the lens of constitutional political economy.

The design of major constitutional rules, such as electoral systems, plays a crucial role in shaping both local taxation and transfers from the central government. By applying a theoretical framework based on political economy and taking into account the specificity of Polish municipalities (our empirical laboratory), we test the hypothesis that proportional electoral systems result in greater revenue from intergovernmental grants than majoritarian electoral systems. Based on the fact that proportional elections introduce higher costs for entering political markets, we reason that, and show that, local councilors and mayors in proportional regimes will be more politicized and arguably will more frequently be members of national political parties, rather than local electoral committees. This in turn leads to an alignment effect between local and central governments, such that central government provides the aligned municipalities with higher intergovernmental grants. This increase in the income from grants has further impacts on the overall financial situation of the 
municipalities: substitution of local financing sources (such as local property taxes) by intergovernmental grants leads to higher vertical fiscal imbalances. We show that these differences between proportional and majoritarian electoral systems have been particularly pronounced after 2002, when the direct election of mayors was introduced and the form of government converted from local parliamentarianism to local presidentialism.

Since the seminal work of Brennan and Buchanan (1980), followed by that of Persson and Tabellini (1999), the question of whether constitutional rules affect fiscal policies has gained considerable attention. The empirical evidence from multi-country studies on how electoral systems and forms of government shape fiscal outcomes is, however, mixed at best. For instance, Persson and Tabellini (2004) demonstrated that electoral systems and forms of government impact budgetary outcomes in a substantial way. They showed that countries with majoritarian rules reduce government expenditure by $3 \%$ of GDP. They also found that, in contrast to parliamentarian regimes, presidential systems result in lower government spending by $6 \%$ of GDP, a smaller welfare state by some $2-3 \%$ and marginally lower budget deficits. Likewise, Cheibub (2006) showed that the gross central government budget balance is systematically higher in presidential than in parliamentary democracies. However, when applying slightly different samples and outcome variables, Blume et al. (2009) were not able to find any robust effects of forms of government on fiscal outcomes.

One issue that makes it particularly difficult to credibly estimate the effects of constitutional rules, is that of omitted variable bias. Cross-country studies suffer from large unobserved heterogeneity in institutions, which cannot be fully identified. Additionally, since the time variation of the rules is typically very limited, researchers deal with relatively small sample sizes (although even potential panel regressions alleviate the omitted variable problem only slightly). In the current paper, we address the above-mentioned obstacles. We test the effect of electoral systems, and to a lesser extent of forms of government, at the local level in a single country. Thus, we deal with a large number of 
observations and we are able to mitigate the problem of omitted variable bias, since in a local setting, the vast majority of institutional characteristics remain constant. Moreover, we analyze a reform introduced by the central government but affecting local entities, which can therefore be considered exogenous.

Another question which remains largely unexplored in the constitutional political economy literature, is that of how the effects of constitutional rules, e.g., electoral systems, depend on other constitutional features, e.g., forms of government (Voigt, 2011). Since most theories on presidentialism and parliamentarianism focus on the relationship between the executive and the legislature, the choice of the electoral system in relation to the legislature seems to be an important interacting variable. In this paper, we explicitly tackle the interaction effects between various constitutional features. We acknowledge that electoral systems display their effects in conjunction with other constitutional rules, notably forms of government.

In our empirical analysis, we exploit a unique quasi-experimental setting at the level of Polish municipalities. Since 1998, municipal councils (local assemblies) in Poland have been elected according to different electoral systems -majoritarian or proportional -depending on a population threshold. In 2002, legislators also decided to introduce direct elections for municipal mayors, effectively changing the form of government in Polish municipalities from parliamentarian to presidential. Although, the reform of 2002 has no (quasi-) experimental flavor, we exploit it to verify the effects of electoral systems before and after the direct elections of mayors was introduced. In this way, we are able to provide a heterogeneity analysis for the effects of electoral systems.

Our results indicate that the discontinuity between municipalities with proportional and those with majoritarian systems can be identified only in the period after 2002, i.e., when direct elections for mayors were first implemented. After 2002, intergovernmental grants increased more in the municipalities with proportional representation. This difference in in- 
tergovernmental grants between municipalities with majoritarian and proportional regimes, can explain the difference in vertical fiscal imbalance between municipalities applying these different electoral regimes. We show that the discontinuity in grants is a result of political alignment between the mayors and the central government. This is much more likely in municipalities with proportional elections. The results are complementary to those of Kantorowicz (2017), who found that in the period 2002-2010, several fiscal and political indicators showed a sharp discontinuity at a population threshold of 20,000 inhabitants.

The next section contains a description of the theoretical considerations. In section 3 , we present the institutional design of Polish municipalities and a detailed description of our natural experiment. Section 4 describes the data set and the empirical approach. Section 5 contains a description of our results and section 6 comprises a set of robustness tests. Section 7 concludes the paper.

\section{Theory}

In this section we provide the theoretical basis for how electoral systems affect intergovernmental grants. Since the causal effect of electoral systems on grants is indirect, we discuss in detail, two mediating variables (transmission channels) linking electoral systems and grants: (1) electoral systems and national political parties and (2) party alignment/favoritism and intergovernmental grants.

\subsection{Electoral Systems and National Political Parties}

There are two features of electoral systems, which have a potentially large effect on the incidence of national political parties versus local associations and independents, particularly in the context of local elections. These are ballot access requirements and seat allocation procedures (Brancati, 2008). 


\subsubsection{Ballot Access Requirements}

There are various requirements concerning the minimum number of signatures from eligible voters needed in order to register a list of candidates for elections. Typically, these signature requirements are not severe, yet national political parties, given their wellestablished infrastructure and organizational and financial capacity, may be in a much better position to gather the required number of signatures, compared to independents and local associations (Brancati, 2008). The signature requirements can be interpreted as barriers to entry. The greater the requirements, the larger these entry barriers are; fewer lists enter the electoral markets and those that do enter are large enough to internalize these barriers. We therefore hypothesize that the larger the signature requirement for registering a list of candidates, the less likely it is that independents and local associations will compete in the elections and the more likely it is that national political parties will do so. We further suggest that national political parties, by putting forward relatively more candidates, will also be more successful in localities where the number of required signatures is large.

Electoral systems also vary in terms of how lists of candidates are, or should be, composed (Brancati, 2008). Proportional elections in particular, require that lists of candidates have at least as many candidates as there are seats in a given district. This largely makes sense as it allows all district seats to be filled in cases where a list wins $100 \%$ of the vote. These requirements are typically less stringent in majoritarian elections. As with the signature requirements, the need for creating a long list of candidates constitutes a barrier to entry. The mobilization and selection of candidates creates costs, which may be more easily internalized by well-established and well-resourced national political parties, compared to independents and local political associations. One could also argue that ballot cards bearing the names of many candidates are much more conducive to the use of recognized

party labels (Gendźwiłł and Żółtak, 2017). All in all, we hypothesize that the greater the 
requirements concerning the number of candidates on an electoral list, the less likely it is that independents and local political associations will compete in the election and the more likely it is that national political parties will do so. By increasing their presence, national political parties will also be relatively more electorally successful in localities which require a larger number of candidates to be registered on a list.

\subsubsection{Seat Allocation Procedures}

Besides ballot access requirements, the main feature determining the prevalence of national political parties vis-à-vis independents and local political associations, is the partyvoter linkage (Carey and Shugart, 1995). In proportional elections, where the distribution of seats depends on votes gathered by the entire party list, voters are much more likely to rely on party cues/shortcuts to make decisions about which candidates to support. Thus, by and large, proportional elections are more party-focused because the fate of candidates is dependent on the performance of the entire party, and this is so even in openlist proportional elections. This differs from majoritarian elections, which are candidatefocused. In these elections, voters are more likely to make their choices based on the qualities of individual candidates rather than those of their parties. This makes the partyvoter link in majoritarian elections looser. This should have the following implications in the context of local electoral systems. National political parties should be attracted to only those elections where party cues and labels matter. Otherwise, national political parties should not enter elections where party labels do not serve their basic functions, (e.g., by reducing the costs of voting) and where the individual characteristics of candidates prevail, such as majoritarian elections. Overall, we hypothesize that proportional electoral systems should be more conducive to encouraging national political parties to compete in local elections, as they induce much more "party competition" than majoritarian elections. 


\subsubsection{Overall Expectations}

National political parties are more likely to compete in, and hence be more electorally successful in, jurisdictions which have more stringent ballot access requirements and jurisdictions with proportional electoral systems, rather than jurisdictions with majoritarian elections.

\subsection{Party Alignment and Intergovernmental Grants}

The fact that local majoritarian and proportional electoral systems induce varying levels of representation from national political parties should not be without consequences for intergovernmental interactions. There are two predominant political economy models for explaining the allocation of grants across levels of government. The first model is the so-called swing-voter model, conceptualized by Lindbeck and Weibull (1987) and Dixit and Londregan (1998). In this model, the upper-level government allocates more grants to subnational governments with a higher proportion of voters who are not attached to any of the parties, i.e., swing voters. The second model, the core-supporters model introduced by Cox and McCubbins (1986), posits that if incumbents are risk-averse, funds are allocated to those subnational governments where voters are clearly supporters of the ruling party. These two models, however, fail to answer a fundamental question: why should the national government transfer funds to lower-tier governments controlled by opposition parties (SoléOllé and Sorribas-Navarro, 2008)?

There are three theoretical models accounting for political alignment between national and subnational governments. For the purpose of this paper, we call these models the "leakage", "signaling" and "electoral assets" models. According to the leakage model, under the assumption that voters are (partially) unaware of the source of the funds, the electoral benefits from grants are shared between national and subnational governments. If that is the case, grants allocated to jurisdictions ruled by parties other the ruling national 
party generate a leakage effect, whereby the national government loses part of the electoral benefit from the grants. Hence, if the recipient of the grant can claim a portion of the credit gained from the grant, the granting government will find it more profitable to allocate grants to aligned rather than unaligned governments (Dasgupta et al., 2004; Arulampalam et al., 2009). This all suggests that subnational governments that are politically aligned with the national government are in a better position to receive grants than the unaligned governments, since national governments are interested in improving the electoral prospects of the whole ruling coalition.

Another rationale for higher intergovernmental grants to politically aligned governments is given in the signaling model (Bracco et al., 2015). In this model, higher grants are correlated with improved public goods provision at the subnational level, which signals the competence of the local government to the electorate. Provided the national government cares about the electoral prospects of politically aligned subnational governments, this provides an incentive for the national government to transfer funds to aligned incumbents, particularly in the period prior to elections. Finally, in the electoral assets model, Brollo and Nannicini (2012) suggest that the national government supports politically aligned subnational governments because aligned lower-tier governments are important electoral assets for central government elections, (e.g., through mobilizing voters for national elections). Thus, national governments are interested in increasing the pool of aligned subnational governments, as they may help in winning national elections. Brollo and Nannicini (2012) further suggest that this tactical distribution may well work through cutting grants to subnational governments ruled by parties other than the ruling party at the national level, particularly if the runner-up is the candidate of the ruling national party. 


\subsubsection{Overall Expectations}

Although these three models provide somewhat different rationales, they all suggest that political alignment between tiers of government induces higher intergovernmental grants. The signaling model of Bracco et al. (2015) further states that the effect of political alignment on grants is especially strong prior to subnational elections. These predictions on the effects of political alignments on intergovernmental grants/transfers find confirmation in the growing empirical literature, e.g., Brollo and Nannicini (2012); Migueis (2013); Bracco et al. (2015); Kauder et al. (2016); Curto-Grau et al. (2018); Toro et al. (2019).

\subsection{Causal Channels}

By reviewing relevant streams of literature on (1) the electoral systems and the incidence of national political parties in local elections and (2) political alignment and intergovernmental grants, we are now in a position to put the pieces of the puzzle together and create an exposition of the full causal chain with accompanying transmission channels. We argue that electoral systems that impose strict ballot access requirements and employ proportional representation, favor national political parties over local political associations and independent candidates. Given that electoral systems with stricter ballot access requirements and proportional representation favor national political parties, they also indirectly induce a higher likelihood of political alignment between national and subnational tiers of government. Lastly, we argue that a higher incidence of political alignment induces tactical distribution of intergovernmental grants.

\section{The Institutional Background}

Municipalities (Polish: gmina) are the principal units of administrative division in Poland, constituting the lowest tier of government. There are currently 2,478 municipalities, varying in size between 1,400 and 1.7 million inhabitants. The legislative and 
Figure 1: The casual channel

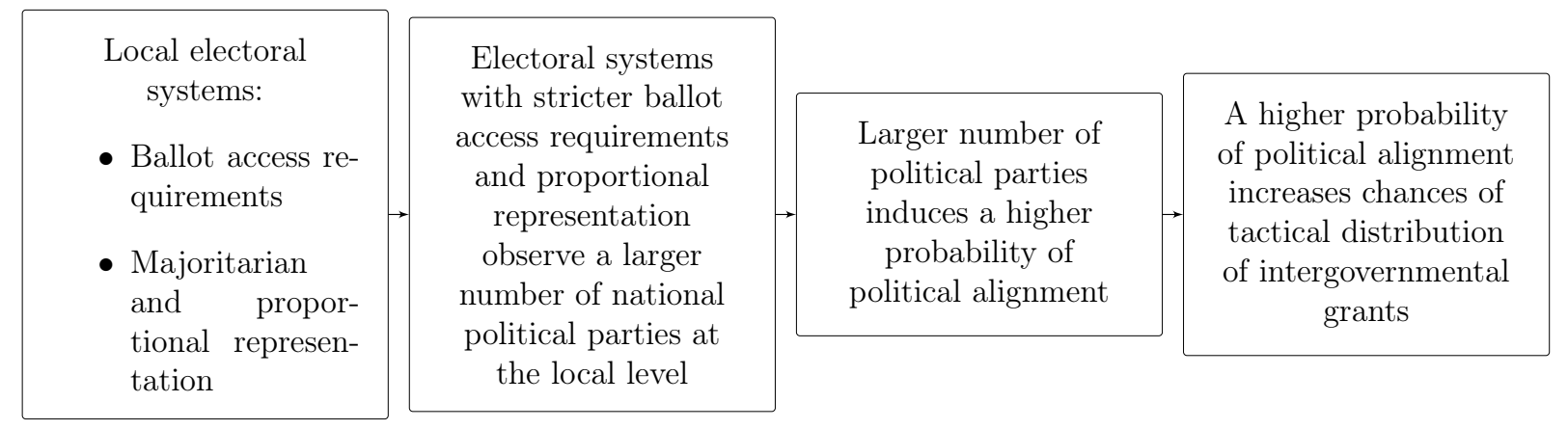

controlling body of each gmina is the elected municipal council (rada gminy) or, in a town, the town council (rada miasta) ${ }^{3}$. Since 2002, executive power has been held by the directly elected mayor of a municipality. Before 2002, the mayor was elected indirectly by the council. The following subsections give a detailed description of the two governing municipal bodies, i.e., the municipal council and the mayor.

\subsection{Municipal Councils and the 1998 Electoral Reform}

Members of the council (councilors) are elected directly from the candidates representing local political associations and/or national political parties. As of 1998, in municipalities with up to 20,000 inhabitants, the council members were elected in majoritarian (plurality) elections. In municipalities with more than 20,000 inhabitants, on the other hand, members of the council were elected by means of a proportional election ${ }^{4}$. In the 2014 elections (based on the law enacted in 2011), the population threshold was removed and a winner-takes-all system was widely introduced. Hence, in this paper, we consider the time period between 1998 and 2010, during which the population threshold of 20,000 clearly delineated the division between majoritarian and proportional electoral systems. The details of the electoral systems and other legal aspects of the 20,000-inhabitant threshold

\footnotetext{
${ }^{3}$ The distinction is a matter of tradition and does not correspond to different competences.

${ }^{4}$ Before 1998 all municipalities below the threshold of 40,000 inhabitants were subject to first-past-thepost electoral systems.
} 
during the years 1998-2010, are summarized in Table 1.

Table 1: Institutional details of electoral systems in the period 1998-2010

\begin{tabular}{|c|c|c|}
\hline & Majoritarian & Proportional \\
\hline Population size & $<20,000$ & $>=20,000$ \\
\hline Electoral rule & Plurality & Proportional (d'Hondt) \\
\hline District magnitude & Up to 5 & $5-8$ \\
\hline No. of signatures to register a party list in a district & Min. 25 & Min. 150 \\
\hline No. of candidates on the list & Min. 1 & Min. 5 \\
\hline \multicolumn{3}{|c|}{ Confounding factors } \\
\hline Council size & 15 & 21 \\
\hline Campaign spending limitation & 750PLN & 1000PLN \\
\hline
\end{tabular}

From Table 1, it is apparent that in municipalities with proportional elections, the costs of entering political markets were much higher (Szczepanowska, 2010), due to the fact that a higher number of signatures was required to register a party list in a district and a larger number of candidates needed to be registered on the list. Furthermore, proportional systems usually introduce the idea of competing elites, ideologies and sectoral interests, where party labels give important cues (Shugart and Carey, 1992; Gendzwill and Zoltak, 2014; Gendźwiłł and Żółtak, 2017). All this leads us to reason that it was much more difficult for local political associations to penetrate local political markets under proportional elections, but rather easy for national political parties, which are well-organized and well-resourced ${ }^{5}$. Kantorowicz (2017) show that there is indeed a substantial difference in the share of council members affiliated with political parties under majoritarian and proportional systems. In the following section, we show that a similar trend (higher levels of politicization in proportional systems) can also be found in the case of mayors.

There are two policies which also vary at the population threshold of 20,000 and could potentially confound the effect of electoral systems. These are council size and campaign spending limits. In the robustness section, we demonstrate that council size does not shape fiscal outcomes. To this end, we exploit the fact that during the years 1990-2002, the

\footnotetext{
${ }^{5}$ It is important to underline the fact that before the 1998 elections, national political parties were banned from putting candidates forward in local elections. They could merely support particular candidates or local committees (Kotarba, 2016).
} 
size of the council was determined by several different population thresholds ${ }^{6}$. Regarding campaign expenditure limits, there is evidence that these are not strictly enforced, and thus are not binding (Szyszko, 2014). It is a well-known practice in Poland for parties to engage in so-called "pre-campaigning", in order to circumvent expenditure limits. This means that politicians begin agitation before the beginning of the official campaign, i.e., when the expenses of campaigning go unreported (Szyszko, 2014). This problem has been recognized by the ombudsman and the National Electoral Commission. To the best of our knowledge, these are the only changes at the 20,000 threshold which could confound our treatment.

\subsection{The Mayor and the 2002 Reform of Forms of Government}

The 1990 law on self-governance stipulated that executive power in a municipality is held by the municipal board (zarzad gminy), a collegial body of between four and seven members, elected by an absolute majority of council members ${ }^{7}$. The mayor, although a member of the board, was elected in a separate ballot. The municipal board could easily be recalled from office by the council. Initially, there were no precisely established procedures for recalling the board. This meant that dismissal of the board, and especially the mayor, could occur for any reason and at any time. A proposal for dismissing the mayor needed to be supported by the same majority required to appoint him. Over time, the procedures for recalling the board were tightened. Dismissal could occur in a situation where the mayor

\footnotetext{
${ }^{6}$ In the robustness section we exploit three out of nine population thresholds determining council size before 2002. It should be noted that the 2002 reform of the councils largely simplified the rules concerning council size. After the reform there were only three population thresholds at which council size could change, namely, 20,000, 50,000 and 100,000. The reform's primary aim was to reduce the number of council members. Whereas before 2002 councils had 24 members in municipalities with a population size below 20,000 and 28 members in municipalities with a population above this threshold, in 2002 these numbers were reduced to 15 and 21 members for the municipalities below and above the cutoff respectively.

${ }^{7}$ Board members could be elected from among councilors. This served to forge better links between the council and the executive body and to make their relationship more workable. However, since the board largely performed a managerial role (executing laws enacted by the council), the idea was also to enable the appointment of the best possible managers from the pool of candidates outside the council (Kotarba, 2016).
} 
failed to receive a vote of confidence, or when a substantiated proposal for recalling the board (or mayor alone) was supported by a quarter of the councilors. In spite of these changes, the position of the municipal executive branch was weak and almost entirely dependent on the council. In such circumstances, the mayor was often forced to conduct his policies in such a way as to please council members, or even to offer them personal favors (Kowalik, 2003). Additionally, the fact that the mayor was not directly elected and was only a member of a collegial body, implied that he could hardly be held personally responsible for his decisions. All in all, a mayor in this system was not seen as representing a separate administrative body. The competence of the mayor was primarily in chairing the board, convening meetings and setting meeting dates. Equally important was the management of the daily affairs of the municipality (Marszał, 2006) and the drafting of laws at the demand of the council. This very much resembled the parliamentary form of governance, as practiced at central levels of government.

As a result of the weak role of the board, the lack of accountability and frequent competence clashes between the mayor and the council, the form of government was reformed. The intention was to introduce direct elections for the mayor, who would from then on constitute a separate, legitimate, one-person executive body in the municipality. Curiously enough, the strengthening of the mayor's position was not combined with shifting competences from the council to the mayor. Apart from some minor changes, the distribution of competences between the mayor and the council remained largely the same. The council was still officially in charge of "determining the mayor's actions". The strengthening of the mayor's position was driven by the fact that he was directly and independently elected by local voters. This could be framed as a de facto strengthening of the mayor's position, since legally the position had not changed a great deal.

As the mayor was directly elected, the council lost all direct means of recalling the mayor from office, and hence the mayor was not dependent on the council. Currently, only 
voters can recall the mayor, via a popular referendum which can be launched at the request of the council. In practice, this is a highly ineffective way of disciplining the mayor. If the proposal for recalling the mayor does not find support in the referendum, the council must be dissolved by law. Since the turnouts in local referenda are very low, the dismissal of a mayor occurs only very rarely. Thus, even though the procedure for "impeachment" is clear, it effectively only strengthens the position of the mayor. A strong public mandate combined with individual responsibility has led to an increasing role for mayors as leaders of local communities. This is evidenced by the fact that around $90 \%$ of legislative initiatives come from the mayor's office (Stępień, 2015).

All in all, the mayor enjoys the position of an executive which is similar to the position of an executive under the presidential form of government. Firstly, the executive is directly elected for a fixed time period and secondly, the executive is neither appointed nor able to be dismissed via a parliamentary vote (Sartori, 1997). In the context of Poland, some refer to this system as "local presidentialism" (Kociubinski, 2015).

It is also important in our context that, according to the law, only parties and local associations that are registered in the majority of electoral districts can register a candidate for mayor. Since, ceteris paribus, in proportional systems there are relatively more national parties registered than in majoritarian systems, this also means that in proportional systems there will be more mayoral candidates registered as candidates of political parties, and hence more mayors affiliated with national parties. As Figure 2 demonstrates, the likelihood that a particular mayor will represent a national political party is much higher above the population threshold of 20,000 than below it. The mechanism that creates this pattern is rather straightforward. The fact that mayors in proportional systems are more politicized should be relevant for intergovernmental fiscal policies.

Given that in the system with a directly elected mayor (local presidentialism), the most important division in the council originates from the mayoral elections (Gendźwiłł 
Figure 2: Share of partisan mayors

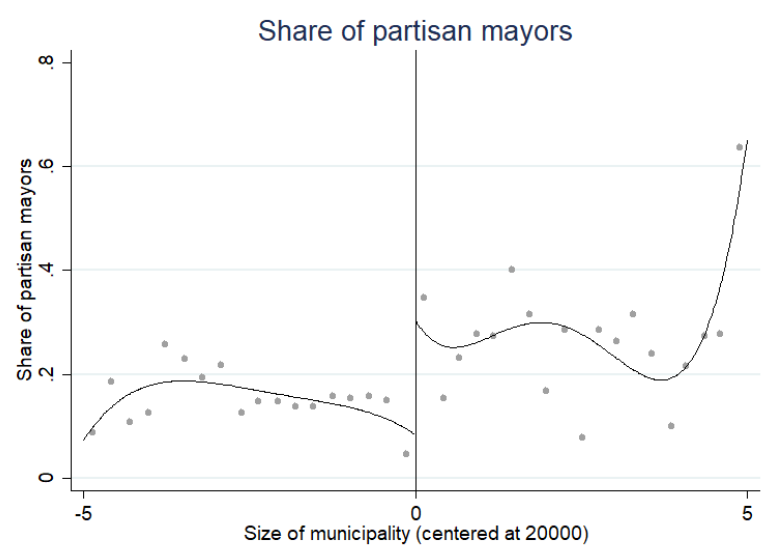

x-axis: Population in 1,000s centered around the 20,000 threshold; y-axis: share expressed in decimals.

and Żółtak, 2017), we focus our analysis on the alignment between the national government and the mayor. To further substantiate this choice, we report the results from the recent $\mathrm{CBOS}^{8}$ surveys. According to this survey, conducted on a representative sample of Poles, $80 \%$ of respondents knew the name of the mayor of their municipality, while only $52 \%$ knew the name of at least one council member (Gendźwiłł and Żółtak, 2017). This further confirms that the mayor is a recognizable local figure and that the political identity of the mayor is of crucial importance. To account for the fact that the position of mayor vis-àvis the council was not always so strong (notably before 2002 when a mayor was elected indirectly), we perform a heterogeneity analysis to compare the effects electoral systems before and after the mayoral reform.

\subsection{Revenues from Intergovernmental Grants}

Municipalities in Poland dispose of revenues from five major sources: subsidies from the central government (Polish: subwencja ogolna), targeted intergovernmental grants (Polish: dotacje celowe), shares of personal and corporate income taxes, local taxation and revenue stemming from the management of municipal property. Municipalities' degrees of freedom

\footnotetext{
${ }^{8}$ Centrum Badania Opinii Społecznej (CBOS) (Centre for Public Opinion Research)
} 
in raising income differ among these diverse categories of financing. In the first two categories, municipalities have virtually no financial independence. It is, however, crucial to make a distinction between subsidies and targeted intergovernmental grants. While the former are purely formula-based transfers, grants are mostly discretionary and are politicized. In $2014,58 \%$ of all transfers from the central government level took the form of subsidies, and the remaining $42 \%$ were discretionary grants. Overall, intergovernmental transfers (subsidies and grants together) constituted on average $57 \%$ of municipalities' revenues in 2014, with maximum values reaching almost $90 \%$ in some cases. In the empirical part of this paper, we will be interested in testing the effects of electoral systems on targeted (discretionary) intergovernmental grants, as these are more dependent on politicized decisions. We will also show that the fact that electoral rules affect the allocation of grants, also impacts indirectly on the revenue from local taxation, as larger intergovernmental grants can substitute for taxes levied locally. This has further implications for the ratio of vertical fiscal imbalance (transfer dependency).

\section{Data and Empirical Approach}

Our sample contains 32,217 observations on Polish municipalities between 1998 and 2010. In 2002, 2,129 of the municipalities were inhabited by fewer than 20,000 persons, and therefore majoritarian voting was implemented in these municipalities. In 336 municipalities, the proportional voting rule was in place ${ }^{9}$. The exact distribution of municipalities around the threshold and the geographical distribution of the analyzed electoral systems are presented in Figure A.6 and Figure A.7 in Appendix A, respectively. Data were collected from several sources. Demographic and fiscal variables were obtained from the Local

\footnotetext{
${ }^{9}$ In other years, the numbers might be slightly different, as some municipalities' changing populations may cause them to cross the threshold. In the year 2002, one municipality crossed the threshold from the majoritarian to the proportional system and in 2006, five municipalities crossed from the proportional to the majoritarian system. We address these changes in the robustness section.
} 
Data Bank of the Central Statistical Office of Poland. Electoral data were collected from the official electoral records of the Polish National Election Commission (PKW). Since elections take place in autumn, it is likely that any fiscal effects would be observed only after one year, i.e., our variables relating to the electoral systems and direct election of the mayor are both subject to a one-year lag. Definitions of the variables are presented in Table 2. Descriptive statistics relating to the variables are presented in Table 3.

Table 2: Definitions of the variables

\begin{tabular}{ll}
\hline \hline Population in units of 1,000 & Population expressed in units of 1,000 normalized so that 20,000=0 (PKW) \\
Majoritarian Election & Equals 1 if normalized population $<0$ (PKW) \\
Direct Mayor & Equals 1 in years 2003 to $2010(\mathrm{PKW})$ \\
VFI & 1 - the ratio of own income to overall income, i.e., transfer dependency (GUS) \\
Grants & Real (inflation $1996=100)$ grants per capita (logarithm) (GUS) \\
Property taxes & Real (inflation $1996=100)$ income from property taxation per capita (loga- \\
& rithm) (GUS) \\
\hline \hline
\end{tabular}

Table 3: Descriptive statistics: municipalities between 18,000 and 22,000 inhabitants

\begin{tabular}{lrrrrr}
\hline \hline Variable & Mean & SD & $\mathrm{N}$ & Min & Max \\
\hline Direct election=0 & & & & & \\
VFI & .593 & .135 & 527 & .231 & .944 \\
(log) property tax p.c. & 4.87 & .628 & 574 & 1.95 & 6.56 \\
(log) grants p.c. & 5.58 & .214 & 535 & 4.94 & 6.26 \\
Direct election=1 & & & & & \\
VFI & .522 & .137 & 1120 & .17 & .862 \\
(log) property tax p.c. & 5.74 & .525 & 1,126 & 4.05 & 7.45 \\
$(\log )$ grants p.c. & 5.81 & .285 & 1,126 & 5.04 & 6.83 \\
Total & & & & & \\
VFI & .545 & .14 & 1647 & .17 & .944 \\
(log) property tax p.c. & 5.45 & .696 & 1,700 & 1.95 & 7.45 \\
(log) grants p.c. & 5.74 & .287 & 1,661 & 4.94 & 6.83 \\
\hline \hline
\end{tabular}

Since the assignment of electoral rules is a function of population with a clear cutoff point at the level of 20,000 inhabitants, a standard way to explore this quasi-experimental setup is by using a regression-discontinuity (RD) design. Since we also aim to analyze how the electoral systems differently affect the fiscal outcomes before and after the 2002 reform introducing the direct election of the mayor, we shall employ a heterogeneity analysis of the effects before and after the reform. This can be parametrically specified as a basic local linear regression model, restricted to observations around the population cutoff $p_{i t} \in$ 
$\left[p_{c}-h, p_{c}+h\right]$, where $p_{c}$ is the cutoff value, taking the form

$$
y_{i t}=\alpha_{0}+\alpha_{1} \times p_{i t}+M_{i} \times\left(\gamma_{0}+\gamma_{1} \times p_{i t}\right)+D_{t}\left[\delta_{0}+\delta_{1} \times p_{i t}+M_{i}(\underbrace{\beta_{0}}_{\text {Interaction effect }}+\beta_{1} \times p_{i t})\right]+\varepsilon_{i t}
$$

In the above equation, $M_{i}$ is a dummy variable for municipalities with majoritarian elections, $D_{t}$ is a dummy for periods from 2003 (recall that this variable led the others) onwards and $\beta_{0}$ measures the heterogeneous impact of direct elections on municipalities below and above the threshold. The term $y_{i t}$ denotes the outcome variable, i.e., intergovernmental grants per capita (real values), and in further specifications, property tax income per capita (real values) and the vertical fiscal imbalance. Standard errors are clustered at the municipality level. The choice of main bandwidth follows the procedure described by Calonico et al. (2014), but other bandwidths are also tested for determining the sensitivity. This basic specification can be further augmented by additional covariates that explain the outcome variables, provided these are continuous at the cutoff population size -a common practice in applied RD studies. However, a recent study by Calonico et al. (2016) suggests that adding further covariates does not resolve the issue of identification (if the continuity assumption fails), does not affect the point estimates and only slightly adds to the efficiency of estimations. On the other hand, including interaction terms of other covariates with the treatment variable makes the RD estimator inconsistent -which in practical terms means that if additional covariates are a channel of transmission through which the treatment works, one risks inconsistencies (see Calonico et al., 2016). Given little gain and a potentially high risk, we abstain from using covariates and include only time and province fixed effects (provinces include between 83 and 314 municipalities each). Nevertheless, we need to make sure that all possible covariates are continuous at the threshold. This is tested and presented in Appendix B.

Alternatively, one can apply polynomial smoothing at both sides of the cutoff before 
and after the reform and compare the size of the discontinuity at the cutoff value (see, Grembi et al., 2016, for more details). The nonparametric approach to heterogeneity for a regression discontinuity design was proposed by, e.g., Hsu et al. (2016). We therefore also show the size of the discontinuity in the variables, before and after the 2002 reform.

Secondly, we are interested in the question of whether the electoral system does indeed work through the hypothesized alignment channel. Therefore, we will take a closer look at the changes to the alignment around the threshold, to determine whether changes in the outcomes of interest do indeed depend on the alignment. In this case, however, one needs to be aware that, since alignment is an endogenous variable, a clear causal interpretation is not possible. Since we hypothesize that the electoral system works, inter alia, through the alignment channel, it is impossible to clearly distinguish between the direct and the indirect effects of the electoral system, without referring to an exogenous instrumental variable as a mediator (see, Frölich and Huber, 2017, for more details). Further details on the empirical investigations into the channel of transmission are given in section 5.2.

For the RD design, some assumptions must be made, in order to identify the local treatment effect. Firstly, the treatment assignment must be a monotonic deterministic function of the assignment variable. This holds true in our study, as exogenously determined electoral law fully determines the assignment to treatment.

Secondly, identification is possible only if municipalities are not able to manipulate the assignment variable. We need to establish whether manipulation of the running variable is, or is not, an issue in our study. The density of the assignment variable for the whole period is presented in Figure B.8 in Appendix B. The confidence intervals are evaluated using McCrary (2008) standard errors. Visual inspection of Figure B.8 and evaluation of the test statistic suggest that manipulation of the forcing variable is not a problem in our design. The estimated log-difference $(\theta)$ at the height of the probability distribution is -0.04 and the p-value of the test is 0.957 . Therefore, we do not reject the null hypothesis 
that the variable is not sorted. Moreover, in our heterogeneity analysis over time, we need to ensure that the densities are constant over time, or in other words, we need to test for sorting before the reform, as well as for sorting differences in the densities. The p-values of the test for the years 1998, 2010 and the difference, are equal to $0.444,0.217$ and 0.732 respectively. In addition, for the case of the subsamples before and after the reform of 2002, there are no visible differences: the p-values were 0.676 and 0.665 respectively.

In the absence of treatment, the outcome variable must evolve continuously with the assignment variable in the neighborhood of the threshold. In other words, confounded treatment should be excluded. If other factors create discontinuities in this relationship, a clear identification of the local treatment effect is not possible. One potential distortion in our setup could arise from the discontinuity in the council size at some population thresholds. We address this issue in the robustness section.

Finally, covariates that potentially affect the development of the outcome variable must be continuous at the threshold. The most obvious candidates for affecting the level of discretionary grants are structural variables related to the socioeconomic development of the municipalities. The central government could be willing to provide more means to economically weaker municipalities. These variables are: dependent population (percentages of younger and older persons), population density, unemployment, levels of public debt, income from personal income taxation and net migration. The continuity of the first four variables can be seen in Figure B.9 in Appendix B, which demonstrates that the covariates do not show discontinuities at the threshold. The latter two variables are presented in more detail later in the robustness section, in the discussion of potential channels of transmission. 


\section{Results}

\subsection{Intergovernmental Grants as a Function of the Electoral System}

We begin describing the results by visually illustrating the discontinuity in intergovernmental grants per capita before and after the 2002 reform. As can clearly be seen in Figure 3, for both fiscal outcomes, a small discontinuity at the 20,000 population threshold can be identified before the 2002 reform. In the municipalities with majoritarian elections, the grants per capita were smaller than in the municipalities with proportional electoral regimes. The discontinuity appears to be larger in the period after the 2002 reform introducing direct election of mayors. This could be considered a prima facie confirmation of our hypotheses derived in section 2. However, in the following discussion we present the formal results of the regressions.

Figure 3: Discontinuity in intergovernmental grants before (blue) and after (red) the reform

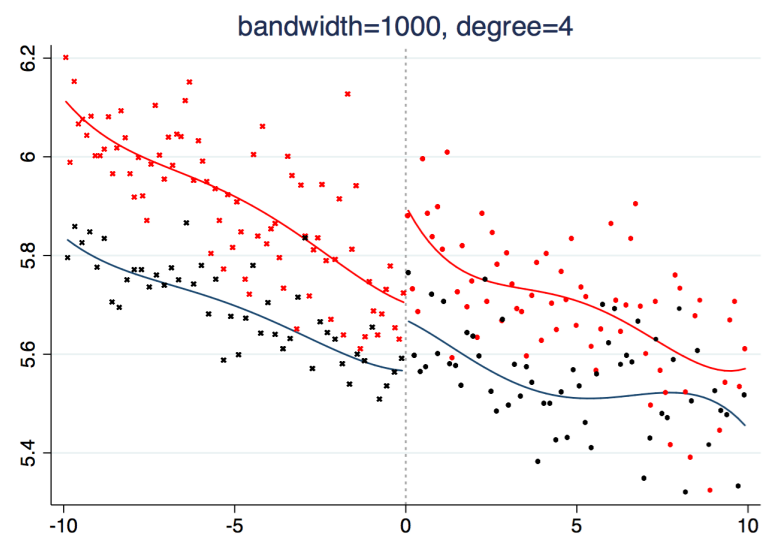

Table 4 shows the main results of the parametric estimation. It was found that intergovernmental grants increased in municipalities with majoritarian elections after the 2002 reform, but not as much as in the municipalities with proportional regimes. The size of the effect is about $15 \%$.

Similar results are presented in Table 5, which shows the nonparametric estimations before and after 2002, for polynomials of order one to three. Nonparametric estimation 
Table 4: Grants from the central government per capita (logarithm): local linear regression, bandwidth $=2,000$ (columns 1 and 2), according to CCT (columns 3 and 4) and 5,000 (columns 5 and 6), with time and province fixed effects

\begin{tabular}{|c|c|c|c|c|c|c|}
\hline & $\begin{array}{c}(1) \\
\mathrm{h}=2000\end{array}$ & $\begin{array}{c}(2) \\
\mathrm{h}=2000\end{array}$ & $\begin{array}{c}(3) \\
\mathrm{h}=1964\end{array}$ & $\begin{array}{c}(4) \\
\mathrm{h}=1964\end{array}$ & $\begin{array}{c}(5) \\
\mathrm{h}=5000\end{array}$ & $\begin{array}{c}(6) \\
\mathrm{h}=5000\end{array}$ \\
\hline Majoritarian Election $=1$ & $\begin{array}{l}-0.09^{*} \\
(-1.69)\end{array}$ & $\begin{array}{c}0.03 \\
(0.80)\end{array}$ & $\begin{array}{l}-0.08 \\
(-1.44)\end{array}$ & $\begin{array}{c}0.03 \\
(0.68)\end{array}$ & $\begin{array}{c}-0.12^{* * *} \\
(-3.85)\end{array}$ & $\begin{array}{l}-0.01 \\
(-0.24)\end{array}$ \\
\hline Direct Mayor $=1$ & $\begin{array}{c}0.18^{* * *} \\
(3.65)\end{array}$ & $\begin{array}{c}0.27^{* * *} \\
(6.41)\end{array}$ & $\begin{array}{c}0.18^{* * *} \\
(3.53)\end{array}$ & $\begin{array}{c}0.26^{* * *} \\
(6.10)\end{array}$ & $\begin{array}{c}0.14^{* * *} \\
(4.26)\end{array}$ & $\begin{array}{c}0.20^{* * *} \\
(6.25)\end{array}$ \\
\hline Majoritarian Election $=1 \times$ Direct Mayor $=1$ & $\begin{array}{l}-0.15^{*} \\
(-1.83)\end{array}$ & $\begin{array}{c}-0.17^{* * *} \\
(-2.67)\end{array}$ & $\begin{array}{l}-0.15^{*} \\
(-1.71)\end{array}$ & $\begin{array}{c}-0.14^{* *} \\
(-2.20)\end{array}$ & $\begin{array}{c}-0.01 \\
(-0.22)\end{array}$ & $\begin{array}{l}-0.07^{*} \\
(-1.90)\end{array}$ \\
\hline Constant & $\begin{array}{c}5.68^{* * *} \\
(114.13)\end{array}$ & $\begin{array}{c}5.58^{* * *} \\
(117.00)\end{array}$ & $\begin{array}{c}5.67^{* * *} \\
(111.32)\end{array}$ & $\begin{array}{c}5.59^{* * *} \\
(110.08)\end{array}$ & $\begin{array}{c}5.69^{* * *} \\
(208.06)\end{array}$ & $\begin{array}{c}5.59^{* * *} \\
(190.90)\end{array}$ \\
\hline Observations & 1,033 & 1,033 & 1,003 & 1,003 & 2,980 & 2,980 \\
\hline Time effects & $\mathrm{NO}$ & YES & $\mathrm{NO}$ & YES & $\mathrm{NO}$ & YES \\
\hline Province effects & NO & YES & $\mathrm{NO}$ & YES & $\mathrm{NO}$ & YES \\
\hline
\end{tabular}

points to about an eight- to 10-percentage-point discontinuity in the revenue from grants after 2002 .

\subsection{Channel of Transmission}

Our hypothesized channel of transmission is the ability of mayors to obtain higher grants from the upper-level governments. As we have initially shown, above the threshold of 20,000, the share of partisan mayors increases. Moreover, we can show that the political alignment of the mayors also sharply increases at the analyzed threshold. We define it as alignment if the mayor is a member of any of the coalition partners at the central level. This definition takes into account the fact that a junior partner of many coalition governments, the Polish People's Party (agrarian Christian democrats), is traditionally well represented at the local level. The discontinuities in alignment for the years 2002-2010 are presented in Table 6. At the threshold, the probability of a mayor belonging to a party which is a coalition partner at the central level, increases by about 20 percentage points.

Once we have established that the probability of alignment between the mayor and the central government increases stepwise at the 20,000 threshold, we still need to show 
Table 5: Grants before and after 2002 -nonparametric estimation

\begin{tabular}{|c|c|c|c|c|c|c|}
\hline & $\begin{array}{c}(1) \\
\text { Before } 2002\end{array}$ & $\begin{array}{c}(2) \\
\text { Before } 2002\end{array}$ & $\begin{array}{c}(3) \\
\text { Before } 2002\end{array}$ & $\begin{array}{c}(4) \\
\text { After } 2002\end{array}$ & $\begin{array}{c}(5) \\
\text { After } 2002\end{array}$ & $\begin{array}{c}(6) \\
\text { After } 2002\end{array}$ \\
\hline RD Estimate & $\begin{array}{l}0.079^{*} \\
{[0.036]}\end{array}$ & $\begin{array}{l}0.083^{*} \\
{[0.041]}\end{array}$ & $\begin{array}{c}0.069 \\
{[0.053]}\end{array}$ & $\begin{array}{c}0.108^{* * * *} \\
{[0.030]}\end{array}$ & $\begin{array}{c}0.123^{* * *} \\
{[0.033]}\end{array}$ & $\begin{array}{l}0.079^{*} \\
{[0.034]}\end{array}$ \\
\hline Robust $95 \%$ CI & {$[-.013, .156]$} & {$[-.01, .173]$} & {$[-.047, .184]$} & {$[.031, .156]$} & {$[.064, .204]$} & {$[.013, .153]$} \\
\hline Kernel Type & Triangular & Triangular & Triangular & $=$ Triangular & Triangular & Triangular \\
\hline BW Type & $\mathrm{CCT}$ & $\mathrm{CCT}$ & $\mathrm{CCT}$ & $\mathrm{CCT}$ & $\mathrm{CCT}$ & $\mathrm{CCT}$ \\
\hline Eff. Observations L & 121 & 209 & 225 & 246 & 243 & 466 \\
\hline Eff. Observations R & 112 & 197 & 203 & 220 & 220 & 372 \\
\hline Conventional p-value & 0.028 & 0.044 & 0.188 & 0.000 & 0.000 & 0.020 \\
\hline Robust p-value & 0.098 & 0.081 & 0.246 & 0.003 & 0.000 & 0.020 \\
\hline Order Loc. Poly. (p) & 1 & 2 & 3 & 1 & 2 & 3 \\
\hline Order Bias (q) & 2 & 3 & 4 & 2 & 3 & 4 \\
\hline BW Loc. Poly. (h) & 1.257 & 2.189 & 2.286 & 1.265 & 1.237 & 2.208 \\
\hline BW Bias (b) & 2.064 & 3.190 & 3.013 & 2.594 & 1.942 & 2.939 \\
\hline
\end{tabular}

${ }^{*} p<0.1, * * p<0.05, * * * p<0.01$. Standard errors in brackets.

Table 6: Political alignment of the mayor and the central government -linear (polynomial) probability model in (1)-(4), categorical outcomes model of $\mathrm{Xu}(2017)$ in (5)

\begin{tabular}{|c|c|c|c|c|c|}
\hline & $\begin{array}{c}(1) \\
\text { Aligned }\end{array}$ & $\begin{array}{c}(2) \\
\text { Aligned }\end{array}$ & $\begin{array}{c}(3) \\
\text { Aligned }\end{array}$ & $\begin{array}{c}(4) \\
\text { Aligned }\end{array}$ & $\begin{array}{c}5 \\
\text { Aligned }\end{array}$ \\
\hline RD Estimate & $\begin{array}{l}0.197^{* * *} \\
{[0.038]}\end{array}$ & $\begin{array}{l}0.234^{* * *} \\
{[0.037]}\end{array}$ & $\begin{array}{l}0.204^{* * *} \\
{[0.050]}\end{array}$ & $\begin{array}{l}0.209^{* * *} \\
{[0.054]}\end{array}$ & $\begin{array}{l}0.141^{* * *} \\
{[0.047]}\end{array}$ \\
\hline Robust $95 \%$ CI & {$[.122, .294]$} & {$[.168, .328]$} & {$[.095, .312]$} & {$[.094, .324]$} & {$[0.069,0.255]$} \\
\hline Kernel Type & Triangular & Triangular & Triangular & Triangular & Uniform \\
\hline BW Type & CCT & CCT & CCT & $\mathrm{CCT}$ & $\mathrm{Xu}(2017)$ \\
\hline Eff. Observations L & 344 & 891 & 815 & 1107 & 531 \\
\hline Eff. Observations R & 304 & 664 & 624 & 752 & 408 \\
\hline Conventional p-value & 0.000 & 0.000 & 0.000 & 0.000 & 0.000 \\
\hline Robust p-value & 0.000 & 0.000 & 0.000 & 0.000 & 0.000 \\
\hline Order Loc. Poly. (p) & 1 & 2 & 3 & 4 & 1 \\
\hline Order Bias (q) & 2 & 3 & 4 & 5 & 2 \\
\hline BW Loc. Poly. (h) & 1.755 & 3.752 & 3.534 & 4.423 & 1.563 \\
\hline BW Bias (b) & 2.858 & 5.448 & 4.146 & 5.127 & 3.873 \\
\hline
\end{tabular}


Table 7: Grants dependent on the margin of victory/loss of an aligned candidate

\begin{tabular}{lccc}
\hline \hline & $(1)$ & $(2)$ & $(3)$ \\
\hline RD Estimate & $0.036^{* *}$ & $0.066^{* * *}$ & $0.084^{* * *}$ \\
& {$[0.013]$} & {$[0.018]$} & {$[0.022]$} \\
\hline Robust 95\% CI & {$[.014 ; .071]$} & {$[.036 ; .111]$} & {$[.047 ; .137]$} \\
Kernel Type & Triangular & Triangular & Triangular \\
BW Type & CCT & CCT & CCT \\
Eff. Observations L & 1454 & 1746 & 2117 \\
Eff. Observations R & 1691 & 2121 & 2656 \\
Conventional p-value & 0.006 & 0.000 & 0.000 \\
Robust p-value & 0.004 & 0.000 & 0.000 \\
Order Loc. Poly. (p) & 1 & 2 & 3 \\
Order Bias (q) & 2 & 3 & 4 \\
BW Loc. Poly. (h) & 11.713 & 14.286 & 17.311 \\
BW Bias (b) & 24.287 & 28.035 & 29.450 \\
$*$ p $<0.1,{ }^{* *} p<0.05, * * * p<0.01$. & Standard errors in brackets.
\end{tabular}

that the aligned mayors are indeed more likely to receive higher grants. In order to do so, we proceed as follows. We restrict our attention to the sample of municipalities in which at least one "aligned" candidate entered the local mayoral election. We then look at the results of the elections. In cases where the candidate won, we calculate the margin of victory over the candidate with the second-highest vote count. In cases where the candidate lost, the margin of loss compared to the winner is calculated. Finally, we compare the fiscal outcomes of municipalities in which aligned candidates marginally won, against those where they marginally lost. Since we look at the results close to the $50 \%$ threshold, the small margins are arguably random. A margin of 10, for instance, means that the candidate won the election by $55 \%$ to $45 \%$ of the votes. The results are presented in Table 7 .

Looking at Table 7, we see that the coefficients have the expected signs and are significant in all specifications. The income from grants is higher by some 3-8\% for the aligned candidates who marginally won the election. Tables C.12 and C.13 in Appendix C show that the results are robust to the choice of bandwidth. We present the discontinuity visually in Figure 4. 
Figure 4: Discontinuity in intergovernmental grants

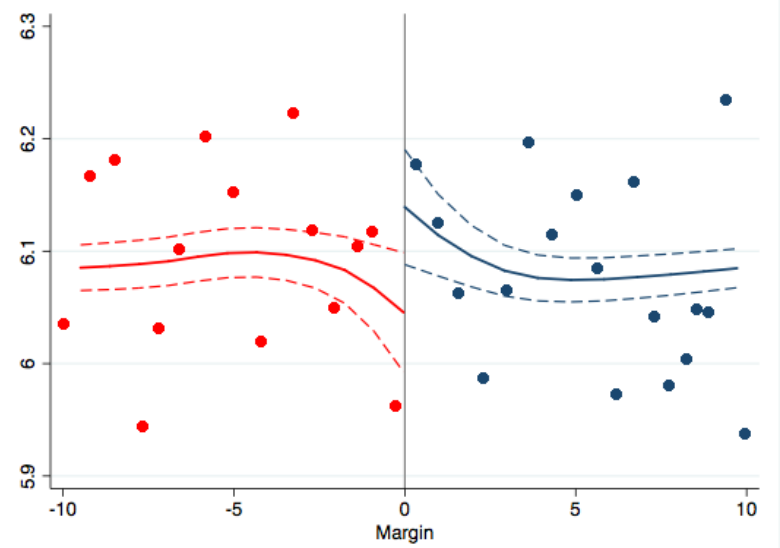

\section{Robustness Checks}

\subsection{Property Taxes and the Vertical Fiscal Imbalance}

As shown previously, the municipalities with proportional electoral systems obtain higher levels of intergovernmental grants than municipalities with majoritarian elections. We further reason that this differential level of intergovernmental grants has an effect on property taxes levied by municipalities. Given that for the local population it may be attractive to bear a lower local tax burden, mayors in proportional electoral systems are in a better position to reduce the property tax burden, due to the fact that forgone revenue from property taxes can be compensated for by higher intergovernmental grants. Revenue from property taxes generates nearly $30 \%$ of all own municipal income. Crucially, municipalities have the freedom to determine the rate of property tax (residential and business buildings and land) up to a ceiling determined by the Ministry of Finance. They can likewise apply preferential rates and exempt certain taxpayers from paying this tax. Overall, municipalities have a great deal of autonomy in levying these taxes. Furthermore, due to these two effects, i.e., higher intergovernmental grants and lower property taxes in proportional systems compared with majoritarian systems, we also expect to identify a difference in vertical fiscal imbalance (the ratio of own income to overall income or transfer 
dependency ratio).

As illustrated in Figure 5, a clear effect can also be observed for property taxes and vertical fiscal imbalance. Under the presidential system (after the 2002 reform), the discontinuity in both property taxes and vertical fiscal imbalance at the 20,000 population threshold is more pronounced than under the parliamentary form of government (before the 2002 reform).

Figure 5: Discontinuities in the VFI before (blue) and after (red) the reform; property taxes (upper panel) and vertical fiscal imbalance (lower panel)

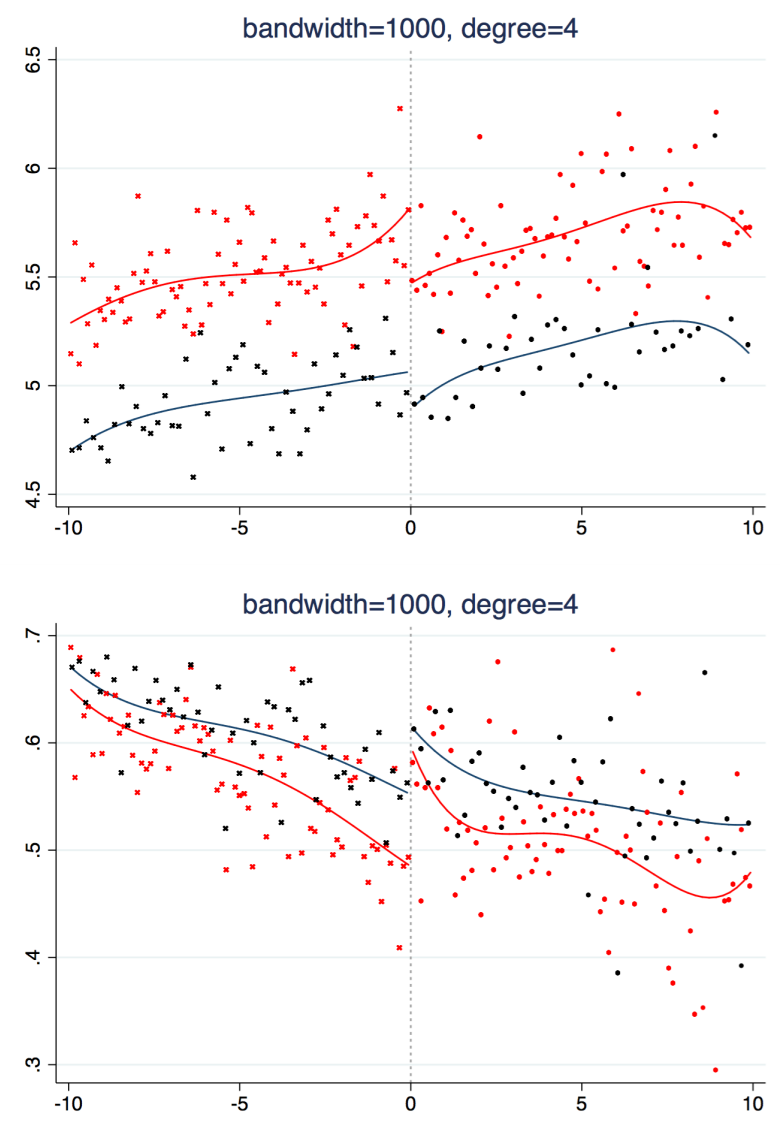

The results in Table 8, however, despite having visual appeal, do not confirm the existence of any systematic differences in property tax income per capita at the 20,000 threshold before the 2002 reform, as the coefficient of "Majoritarian Election=1" is not statistically 
significantly different from zero. Nevertheless, it should be noted that the estimate of the interaction coefficient is statistically significant and positive. The difference in property tax income per capita at the 20,000 population threshold increased over time by approximately 20-40\%. This is an effect of the electoral systems, which are contingent upon the type or forms of government. Thus, after 2002 in municipalities with majoritarian elections, the property tax income per capita increased much more than in the municipalities with proportional elections. The results are further confirmed by the nonparametric estimations in Table 9, which point to the existence of a discontinuity only after 2002.

Table 8: Real own income from property tax per capita (logarithm): local linear regression, bandwidth $=2,000$ (columns 1 and 2), according to CCT (columns 3 and 4) and 5,000 (columns 5 and 6), with time and province fixed effects

\begin{tabular}{|c|c|c|c|c|c|c|}
\hline & $\begin{array}{c}(1) \\
\mathrm{h}=2000\end{array}$ & $\begin{array}{c}(2) \\
\mathrm{h}=2000\end{array}$ & $\begin{array}{c}(3) \\
\mathrm{h}=2118\end{array}$ & $\begin{array}{c}(4) \\
\mathrm{h}=2118\end{array}$ & $\begin{array}{c}(5) \\
\mathrm{h}=5000\end{array}$ & $\begin{array}{c}(6) \\
\mathrm{h}=5000\end{array}$ \\
\hline Majoritarian Election $=1$ & $\begin{array}{c}-0.01 \\
(-0.08)\end{array}$ & $\begin{array}{l}-0.01 \\
(-0.11)\end{array}$ & $\begin{array}{l}-0.06 \\
(-0.47)\end{array}$ & $\begin{array}{l}-0.04 \\
(-0.35)\end{array}$ & $\begin{array}{c}0.03 \\
(0.41)\end{array}$ & $\begin{array}{c}0.02 \\
(0.41)\end{array}$ \\
\hline Direct Mayor $=1$ & $\begin{array}{c}0.44^{* * *} \\
(4.49)\end{array}$ & $\begin{array}{c}0.24^{* * *} \\
(2.83)\end{array}$ & $\begin{array}{c}0.39^{* * *} \\
(3.88)\end{array}$ & $\begin{array}{c}0.21^{* *} \\
(2.24)\end{array}$ & $\begin{array}{c}0.47^{* * *} \\
(7.42)\end{array}$ & $\begin{array}{c}0.29^{* * *} \\
(4.71)\end{array}$ \\
\hline Majoritarian Election $=1 \times$ Direct Mayor $=1$ & $\begin{array}{c}0.37^{* * *} \\
(2.74)\end{array}$ & $\begin{array}{l}0.22^{*} \\
(1.86)\end{array}$ & $\begin{array}{c}0.43^{* * *} \\
(2.95)\end{array}$ & $\begin{array}{l}0.26^{* *} \\
(2.10)\end{array}$ & $\begin{array}{l}0.17^{* *} \\
(2.18)\end{array}$ & $\begin{array}{l}0.05 \\
(0.78)\end{array}$ \\
\hline Constant & $\begin{array}{c}4.97^{* * *} \\
(45.64)\end{array}$ & $\begin{array}{c}5.45^{* * *} \\
(40.64)\end{array}$ & $\begin{array}{l}5.00 * * * \\
(44.02)\end{array}$ & $\begin{array}{c}5.43^{* * *} \\
(37.81)\end{array}$ & $\begin{array}{c}4.99 * * * \\
(95.99)\end{array}$ & $\begin{array}{l}5.56 * * * \\
(99.52)\end{array}$ \\
\hline Observations & 1,033 & 1,033 & 1,102 & 1,102 & 2,980 & 2,980 \\
\hline $\begin{array}{l}\text { Time effects } \\
\text { Province effects }\end{array}$ & $\begin{array}{l}\mathrm{NO} \\
\mathrm{NO}\end{array}$ & $\begin{array}{l}\text { YES } \\
\text { YES }\end{array}$ & $\begin{array}{l}\mathrm{NO} \\
\mathrm{NO}\end{array}$ & $\begin{array}{l}\text { YES } \\
\text { YES }\end{array}$ & $\begin{array}{l}\mathrm{NO} \\
\mathrm{NO}\end{array}$ & $\begin{array}{l}\text { YES } \\
\text { YES }\end{array}$ \\
\hline
\end{tabular}

This visual illustration of differences in the vertical fiscal imbalance is further substantiated by the evidence provided in Table 10. It is clear that the discontinuity in the vertical fiscal imbalance at the 20,000 population threshold could not be observed before the reform of the governance system. Neither is the direct election of mayors responsible for changes in the fiscal imbalances. The interaction between the two effects is, however, highly significant across all specifications. Smaller communes, with majoritarian elections and directly elected mayors, have lower fiscal imbalances than those with the proportional 
Table 9: Property tax before and after 2002 -nonparametric estimation

\begin{tabular}{lcccccc}
\hline \hline & $\begin{array}{c}(1) \\
\text { Before 2002 }\end{array}$ & $\begin{array}{c}(2) \\
\text { Before 2002 }\end{array}$ & $\begin{array}{c}(3) \\
\text { Before 2002 }\end{array}$ & $\begin{array}{c}(4) \\
\text { After 2002 }\end{array}$ & $\begin{array}{c}(5) \\
\text { After 2002 }\end{array}$ & $\begin{array}{c}(6) \\
\text { After 2002 }\end{array}$ \\
\hline RD Estimate & -0.019 & -0.005 & 0.133 & $-0.291^{* * *}$ & $-0.276^{* * *}$ & $-0.345^{* *}$ \\
& {$[0.097]$} & {$[0.114]$} & {$[0.137]$} & {$[0.067]$} & {$[0.079]$} & {$[0.105]$} \\
\hline Robust 95\% CI & {$[-.225, .233]$} & {$[-.242, .261]$} & {$[-.125, .45]$} & {$[-.451,-.134]$} & {$[-.468,-.112]$} & {$[-.598,-.156]$} \\
Kernel Type & Triangular & Triangular & Triangular & Triangular & Triangular & Triangular \\
BW Type & CCT & CCT & CCT & CCT & CCT & CCT \\
Eff. Observations L & 125 & 194 & 198 & 221 & 337 & 352 \\
Eff. Observations R & 118 & 185 & 189 & 203 & 278 & 294 \\
Conventional p-value & 0.848 & 0.966 & 0.329 & 0.000 & 0.001 & 0.001 \\
Robust p-value & 0.970 & 0.941 & 0.269 & 0.000 & 0.001 & 0.001 \\
Order Loc. Poly. (p) & 1 & 2 & 3 & 1 & 2 & 3 \\
Order Bias (q) & 2 & 3 & 4 & 2 & 3 & 4 \\
BW Loc. Poly. (h) & 1.291 & 2.051 & 2.083 & 1.131 & 1.660 & 1.728 \\
BW Bias (b) & 2.049 & 2.872 & 2.907 & 1.578 & 2.152 & 2.452 \\
\hline \hline
\end{tabular}

${ }^{*} p<0.1,{ }^{* *} p<0.05, * * * p<0.01$. Standard errors in brackets.

electoral system. The size of the effect is about six percentage points, and is independent of the bandwidth of the specifications, including fixed and time effects. Given that the average vertical fiscal imbalance is around 57\%, an average reduction of six percentage points is equivalent to a change of about $10 \%$, and thus constitutes a highly significant economic effect.

Table 10: Vertical fiscal imbalance: local linear regression, bandwidth=2,000 (columns 1 and 2), according to CCT (columns 3 and 4) and 5,000 (columns 5 and 6), with time and province fixed effects

\begin{tabular}{|c|c|c|c|c|c|c|}
\hline & $\begin{array}{c}(1) \\
\mathrm{h}=2000\end{array}$ & $\begin{array}{c}(2) \\
\mathrm{h}=2000\end{array}$ & $\begin{array}{c}(3) \\
\mathrm{h}=2217\end{array}$ & $\begin{array}{c}(4) \\
\mathrm{h}=2217\end{array}$ & $\begin{array}{c}(5) \\
\mathrm{h}=5000\end{array}$ & $\begin{array}{c}(6) \\
\mathrm{h}=5000\end{array}$ \\
\hline Majoritarian Election $=1$ & $\begin{array}{c}0.02 \\
(0.52)\end{array}$ & $\begin{array}{c}-0.02 \\
(-0.65)\end{array}$ & $\begin{array}{c}0.02 \\
(0.76)\end{array}$ & $\begin{array}{c}-0.02 \\
(-0.59)\end{array}$ & $\begin{array}{l}0.03^{*} \\
(1.82)\end{array}$ & $\begin{array}{c}0.01 \\
(0.61)\end{array}$ \\
\hline Direct Mayor $=1$ & $\begin{array}{c}0.02 \\
(0.82)\end{array}$ & $\begin{array}{c}0.02 \\
(0.78)\end{array}$ & $\begin{array}{c}0.03 \\
(1.12)\end{array}$ & $\begin{array}{c}0.02 \\
(1.01)\end{array}$ & $\begin{array}{c}-0.00 \\
(-0.25)\end{array}$ & $\begin{array}{c}-0.01 \\
(-0.47)\end{array}$ \\
\hline Majoritarian Election $=1 \times$ Direct Mayor $=1$ & $\begin{array}{c}-0.16^{* * *} \\
(-4.03)\end{array}$ & $\begin{array}{l}-0.06^{*} \\
(-1.85)\end{array}$ & $\begin{array}{c}-0.15^{* * *} \\
(-4.02)\end{array}$ & $\begin{array}{l}-0.06^{*} \\
(-1.72)\end{array}$ & $\begin{array}{c}-0.10^{* * *} \\
(-4.82)\end{array}$ & $\begin{array}{c}-0.04^{* *} \\
(-2.08)\end{array}$ \\
\hline Constant & $\begin{array}{c}0.57^{* * * *} \\
(22.49)\end{array}$ & $\begin{array}{c}0.54^{* * *} \\
(15.99)\end{array}$ & $\begin{array}{c}0.57^{* * *} \\
(21.89)\end{array}$ & $\begin{array}{c}0.54^{* * *} \\
(15.55)\end{array}$ & $\begin{array}{c}0.56^{* * *} \\
(41.24)\end{array}$ & $\begin{array}{c}0.50^{* * *} \\
(34.43)\end{array}$ \\
\hline Observations & 1,023 & 1,023 & 1,154 & 1,154 & 2,958 & 2,958 \\
\hline Time effects & $\mathrm{NO}$ & YES & $\mathrm{NO}$ & $\overline{\mathrm{YES}}$ & $\mathrm{NO}$ & $\overline{\mathrm{YES}}$ \\
\hline Province effects & $\mathrm{NO}$ & YES & $\mathrm{NO}$ & YES & $\mathrm{NO}$ & YES \\
\hline
\end{tabular}

Similarly, the nonparametric estimation of the discontinuity in the vertical fiscal im- 
Table 11: Vertical fiscal imbalance before and after 2002 -nonparametric estimation

\begin{tabular}{lcccccc}
\hline \hline & $\begin{array}{c}(1) \\
\text { Before 2002 }\end{array}$ & $\begin{array}{c}(2) \\
\text { Before 2002 }\end{array}$ & $\begin{array}{c}(3) \\
\text { Before 2002 }\end{array}$ & $\begin{array}{c}(4) \\
\text { After 2002 }\end{array}$ & $\begin{array}{c}(5) \\
\text { After 2002 }\end{array}$ & $\begin{array}{c}(6) \\
\text { After 2002 }\end{array}$ \\
\hline RD Estimate & $0.049^{*}$ & 0.048 & 0.037 & $0.068^{* * *}$ & $0.073^{* * *}$ & $0.090^{* * *}$ \\
& {$[0.023]$} & {$[0.027]$} & {$[0.033]$} & {$[0.016]$} & {$[0.019]$} & {$[0.022]$} \\
\hline Robust 95\% CI & {$[-.01, .097]$} & {$[-.014, .105]$} & {$[-.039, .105]$} & {$[.031, .106]$} & {$[.038, .119]$} & {$[.051, .141]$} \\
Kernel Type & Triangular & Triangular & Triangular & Triangular & Triangular & Triangular \\
BW Type & CCT & CCT & CCT & CCT & CCT & CCT \\
Eff. Observations L & 128 & 198 & 222 & 201 & 273 & 354 \\
Eff. Observations R & 117 & 191 & 202 & 187 & 232 & 296 \\
Conventional p-value & 0.033 & 0.072 & 0.272 & 0.000 & 0.000 & 0.000 \\
Robust p-value & 0.112 & 0.131 & 0.366 & 0.000 & 0.000 & 0.000 \\
Order Loc. Poly. (p) & 1 & 2 & 3 & 1 & 2 & 3 \\
Order Bias (q) & 2 & 3 & 4 & 2 & 3 & 4 \\
BW Loc. Poly. (h) & 1.350 & 2.148 & 2.293 & 1.019 & 1.398 & 1.747 \\
BW Bias (b) & 2.175 & 3.033 & 3.003 & 1.442 & 2.013 & 2.605 \\
\hline \hline
\end{tabular}

${ }^{*} p<0.1,{ }^{* *} p<0.05,{ }^{* * *} p<0.01$. Standard errors in brackets.

balance before and after 2002 is presented in Table 11.

Summarizing, we conclude that the 2002 reform accentuated the discontinuities in the allocation of grants. Moreover, further results regarding property taxation and the overall effect of the sources of financing on the vertical fiscal imbalance, confirm the changes: larger municipalities after 2002 seem to substitute income from local taxation with discretionary grants, which subsequently leads to an increase in the vertical fiscal imbalance. These results are robust to various transmission channels (see Appendix D) and specification tests (see Appendix E).

\section{Conclusions}

In this paper, we apply a regression discontinuity design to verify how constitutional rules, i.e., electoral systems, shape earned (taxes) and unearned (transfers) budget revenues at the subnational government level. We take advantage of a natural experiment, which was triggered by the reform of the electoral systems at the local level in Poland. The reform introduced two electoral rules in 1998 which changed according to an exogenous population threshold: smaller municipalities used majoritarian elections and larger municipalities used 
proportional elections. While intergovernmental grants to the municipalities increased in both small and large municipalities, the increase was less marked in municipalities with majoritarian elections compared to jurisdictions with proportional representation. This differential effect of electoral systems on intergovernmental grants seems to have further implications for revenues from property taxes and vertical fiscal imbalance. These effects of electoral systems were much more pronounced in the time period after 2002, when an indirectly appointed executive was replaced by a directly elected mayor. Thus, the presidential form of government tends to exacerbate the differences between majoritarian and proportional electoral systems. This confirms the existence of an interaction effect between forms of government and electoral rules at the local level in Poland.

Regarding policy implications, our results suggest that the budgetary self-reliance of local governments under the direct election of mayors is best achieved with majoritarian electoral systems for local legislative bodies. Majoritarian elections present a barrier to the penetration of local political markets by national parties, preventing political alignment between local and central governments. Political alignment is crucial, inasmuch as it causes greater transfers from central to local governments, increasing the transfer dependency of municipalities. High reliance on transfers has, in turn, negative implications for, inter alia, public goods provision (Oates, 2001) and the general governmental budget balance (Eyraud and Lusinyan, 2013).

\section{Acknowledgments}

The authors are grateful to the editor and two anonymous referees for their helpful suggestions. The authors acknowledge helpful comments from Alexandra Benham, Lee Benham, Andrea Colombo, Raphaël Franck, Martin Gassebner, Katharina Hofer, Philip Keefer, Christian Keuschnigg, Hans Pitlik and Mary Shirley, as well as the participants of the Silvaplana Workshop on Political Economy 2016, the European Public Choice Society 
Meeting 2017, the 2017 Meeting of the Austrian Economic Association and the 2017 Annual Conference of the Society for Institutional and Organizational Economics. All errors remaining are our own.

This research did not receive any specific grant from funding agencies in the public, commercial or not-for-profit sectors. 


\section{References}

Arulampalam, W., Dasgupta, S., Dhillon, A., Dutta, B., 2009. Electoral goals and centerstate transfers: A theoretical model and empirical evidence from india. Journal of Development Economics 88 (1), 103-119.

Blume, L., Müller, J., Voigt, S., Wolf, C., 2009. The economic effects of constitutions: replicating - and extending - Persson and Tabellini. Public Choice 139 (1-2), 197-225.

Borge, L.-E., Rattso, J., 2008. Property taxation as incentive for cost control: Empirical evidence for utility services in norway. European Economic Review 52 (6), 1035 - 1054. URL http://www.sciencedirect.com/science/article/pii/S0014292107001493

Bracco, E., Lockwood, B., Porcelli, F., Redoano, M., 2015. Intergovernmental grants as signals and the alignment effect: Theory and evidence. Journal of Public Economics 123, $78-91$.

Brancati, D., 2008. Winning alone: the electoral fate of independent candidates worldwide. The Journal of Politics 70 (3), 648-662.

Brennan, G., Buchanan, J. M., 1980. The power to tax: Analytic foundations of a fiscal constitution. Cambridge University Press.

Brollo, F., Nannicini, T., 2012. Tying your enemy's hands in close races: the politics of federal transfers in brazil. American Political Science Review 106 (4), 742-761.

Calonico, S., Cattaneo, M. D., Farrell, M. H., Titiunik, R., 2016. Regression discontinuity designs using covariates. Tech. rep., working paper, University of Michigan.

Calonico, S., Cattaneo, M. D., Titiunik, R., 2014. Robust nonparametric confidence intervals for regression-discontinuity designs. Econometrica 82 (6), 2295-2326. 
Carey, J. M., Shugart, M. S., 1995. Incentives to cultivate a personal vote: A rank ordering of electoral formulas. Electoral studies 14 (4), 417-439.

Cheibub, J. A., 2006. Presidentialism, Electoral Identifiability, and Budget Balances in Democratic Systems. American Political Science Review 100(3), 353-368.

Cox, G. W., McCubbins, M. D., 1986. Electoral politics as a redistributive game. The Journal of Politics 48 (2), 370-389.

Curto-Grau, M., Solé-Ollé, A., Sorribas-Navarro, P., 2018. Does electoral competition curb party favoritism? American Economic Journal: Applied Economics 10 (4), 378-407.

Dasgupta, S., Dhillon, A., Dutta, B., 2004. Electoral goals and center-state transfers: A theoretical model and empirical evidence from india. Unpublished manuscript, University of Warwick.

Dixit, A., Londregan, J., 1998. Fiscal federalism and redistributive politics. Journal of Public Economics 68 (2), 153-180.

Eyraud, L., Lusinyan, L., 2013. Vertical fiscal imbalances and fiscal performance in advanced economies. Journal of Monetary Economics 60 (5), 571-587.

Frölich, M., Huber, M., 2017. Direct and indirect treatment effects-causal chains and mediation analysis with instrumental variables. Journal of the Royal Statistical Society: Series B (Statistical Methodology) 79 (5), 1645-1666.

Gadenne, L., January 2017. Tax me, but spend wisely? sources of public finance and government accountability. American Economic Journal: Applied Economics 9 (1), 274314.

URL http://www . aeaweb.org/articles?id=10.1257/app. 20150509 
Gendzwill, A., Zoltak, T., 2014. Why Do Non-partisans Challenge Parties in Local Politics? The (Extreme) Case of Poland. EUROPE-ASIA STUDIES 66(7), 1122-1145.

Gendźwiłł, A., Żółtak, T., 2017. How single-member districts are reinforcing local independents and strengthening mayors: on the electoral reform in polish local government. Local Government Studies 43 (1), 110-131.

Grembi, V., Nannicini, T., Troiano, U., July 2016. Do fiscal rules matter? American Economic Journal: Applied Economics 8 (3), 1-30.

Hsu, Y.-C., Shen, S., et al., 2016. Testing for treatment effect heterogeneity in regression discontinuity design. Tech. rep., Institute of Economics, Academia Sinica, Taipei, Taiwan.

Kantorowicz, J., 2017. Electoral systems and fiscal policy outcomes: Evidence from poland. European Journal of Political Economy 47, 36-60.

Kauder, B., Potrafke, N., Reischmann, M., 2016. Do politicians reward core supporters? evidence from a discretionary grant program. European Journal of Political Economy $45,39-56$.

Kociubinski, K., 2015. Ewolucja pozycji wojta/burmistrza/prezydenta miasta w systemie polskiego samorzadu gminnego. Spolecznosci lokalne jako miejsca zmian. Teoria i praktyka., $151-162$.

Kotarba, B., 2016. Problemy wspoldzialania organow polskich gmin.

Kowalik, J., 2003. Szanse i zagrożenia bezpośrednich wyborów wójtów i burmistrzów. Samorząd Terytorialny 6.

Lindbeck, A., Weibull, J. W., 1987. Balanced-budget redistribution as the outcome of political competition. Public choice 52 (3), 273-297. 
Marszał, K., 2006. Wpływ bezpośredniego wyboru wójta, burmistrza i prezydenta miasta na lokalny system polityczny. Rocznik Ostrowskiego Towarzystwa Naukowego 1.

Martinez, L. R., 2014. Sources of revenue and government performance: Evidence from colombia. Unpublished Manuscript.

McCrary, J., 2008. Manipulation of the running variable in the regression discontinuity design: A density test. Journal of Econometrics 142 (2), 698-714.

Migueis, M., 2013. The effect of political alignment on transfers to portuguese municipalities. Economics \& Politics 25 (1), 110-133.

Oates, W., 2001. Property Taxation and Local Government Finance, Essays in Honor of C. Lowell Harriss. Lincoln Institute of Land Policy, Cambridge.

Paler, L., 2013. Keeping the public purse: An experiment in windfalls, taxes, and the incentives to restrain government. American Political Science Review 107 (4), 706-725.

Persson, T., Tabellini, G., 1999. The size and scope of government: Comparative politics with rational politicians. European Economic Review 43 (4), 699-735.

Persson, T., Tabellini, G., 2004. Constitutional rules and fiscal policy outcomes. The American Economic Review 94 (1), 25-45.

Sartori, G., 1997. Comparative Constitutional Engineering. Macmillian Press.

Shugart, M. S., Carey, J. M., 1992. Presidents and Assemblies. Constitutional Design and Electoral Dynamics. Cambridge University Press.

Solé-Ollé, A., Sorribas-Navarro, P., 2008. The effects of partisan alignment on the allocation of intergovernmental transfers. differences-in-differences estimates for spain. Journal of Public Economics 92 (12), 2302-2319. 
Stępień, P., August 2015. 25 lat samorządu terytorialnego w Polsce.

Szczepanowska, M., 2010. Ewolucja prawa wyborczego do samorzadu terytorialnego w lataach 1990-2006 w perspektywie partii politycznych, 127-141.

Szyszko, K., 2014. Ile kosztuje mandat radnego? Polityka Warszawska.

Toro, S., et al., 2019. Tactical distribution in local funding: The value of an aligned mayor. European Journal of Political Economy 56, 74-89.

Voigt, S., 2011. Empirical constitutional economics: Onward and upward? Journal of Economic Behavior \& Organization 80 (2), 319-330.

Xu, K.-L., 2017. Regression discontinuity with categorical outcomes. Journal of Econometrics $201(1), 1-18$. 


\section{Appendix A. Size and Spatial Distribution of the Municipalities}

Figure A.6: Number of municipalities by population classes

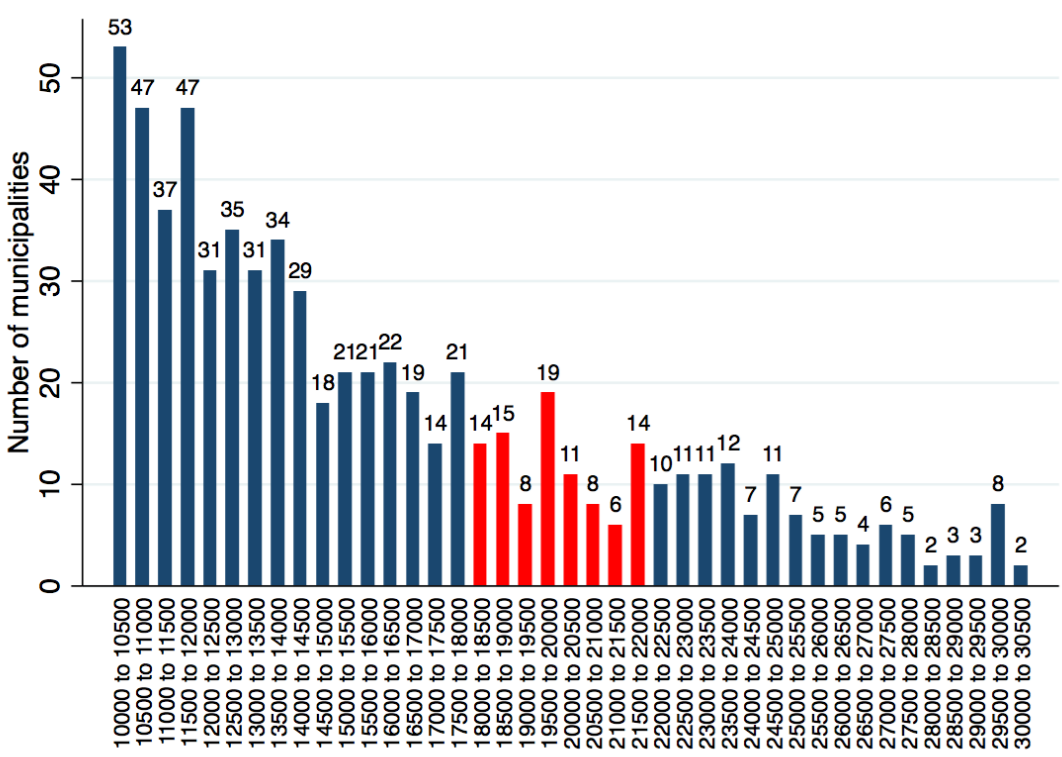

Number of municipalities by classes of 500 in the year 2010;

in red: municipalities between 18,000 and 22,000, which roughly corresponds to the CCT bandwidths.

Figure A.7: Electoral systems in 2010

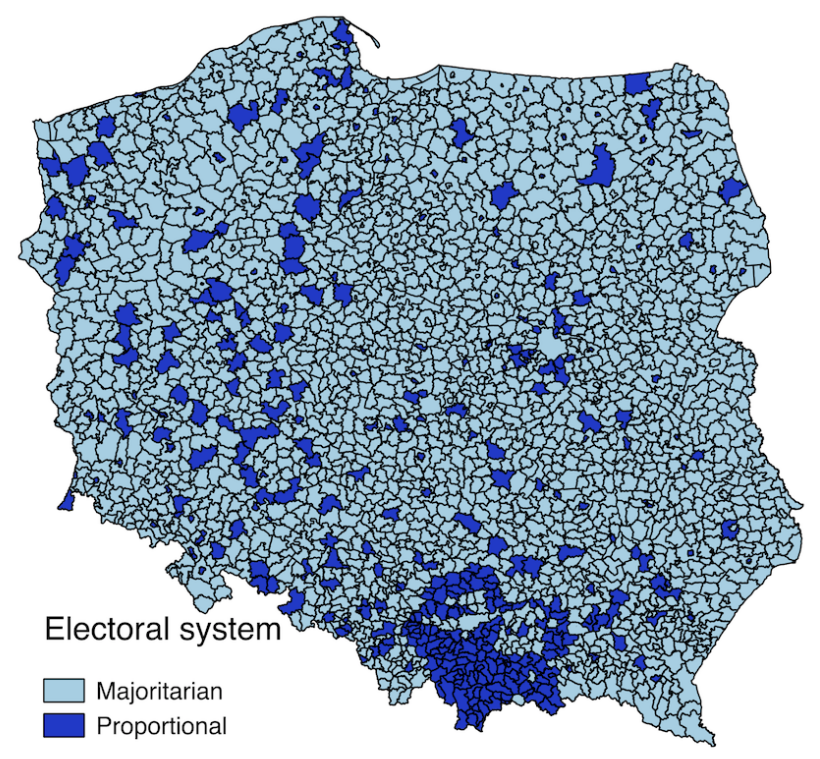




\section{Appendix B. Continuity of the Assignment Variables and Other Covariates}

Figure B.8: Continuity of the assignment variable

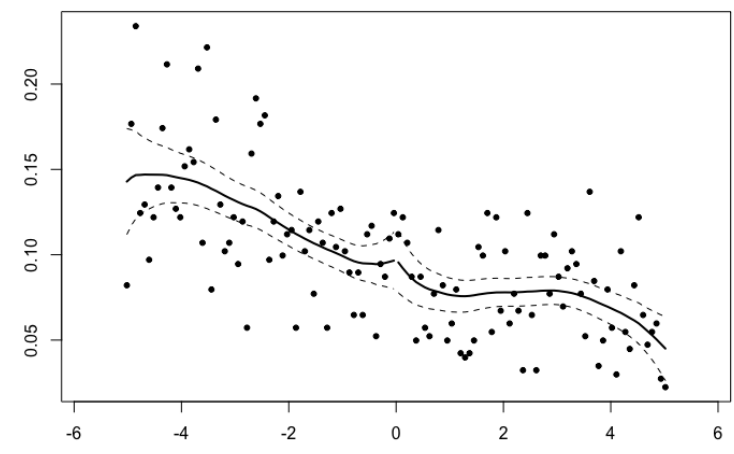

(a) Whole sample

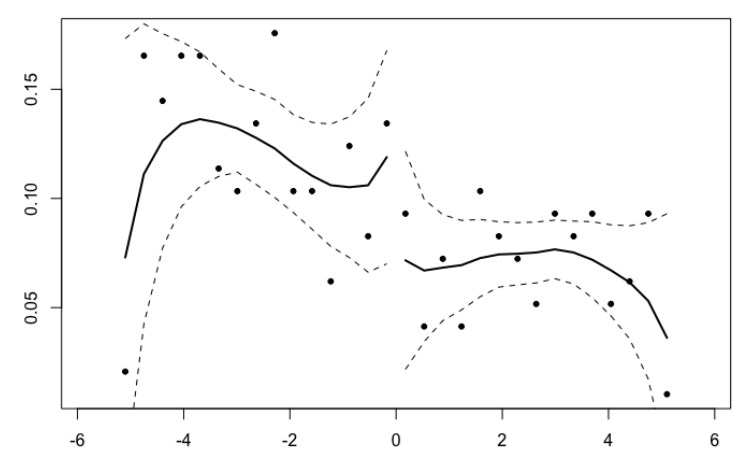

(c) Year 2010

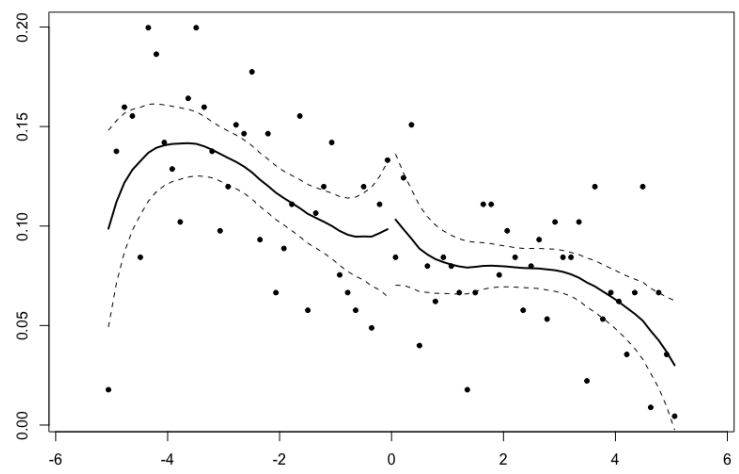

(e) Before 2002

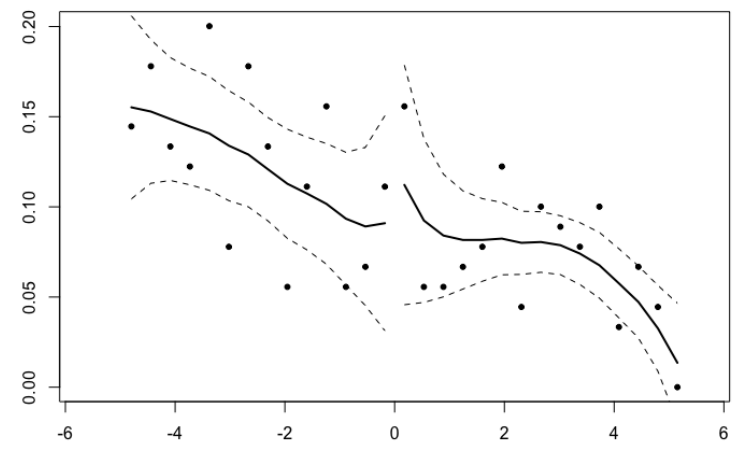

(b) Year 1998

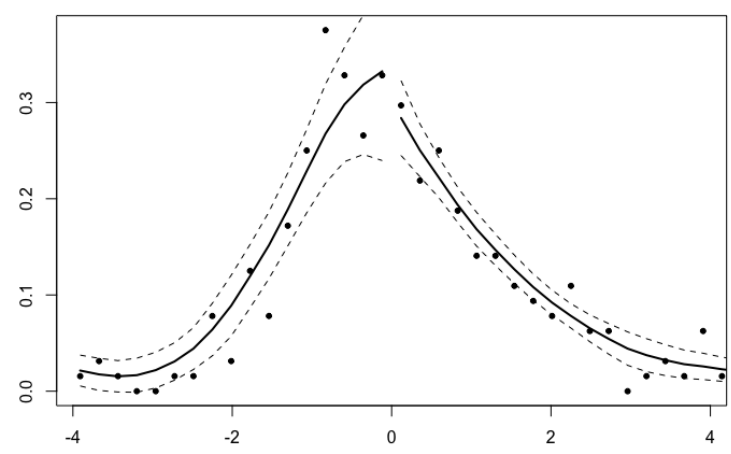

(d) Difference 1998-2010

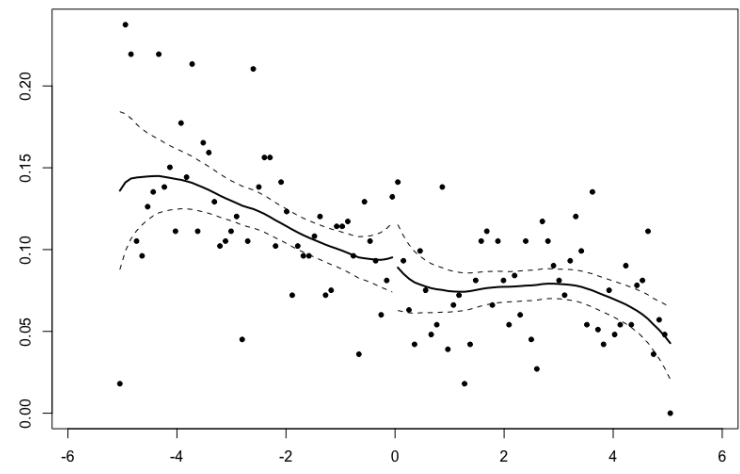

(f) After 2002 
Figure B.9: Continuity of the covariates

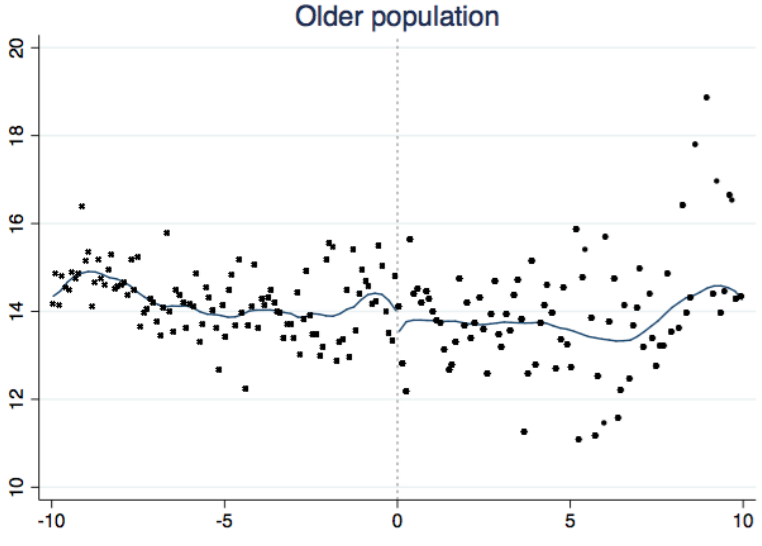

(a) Older population

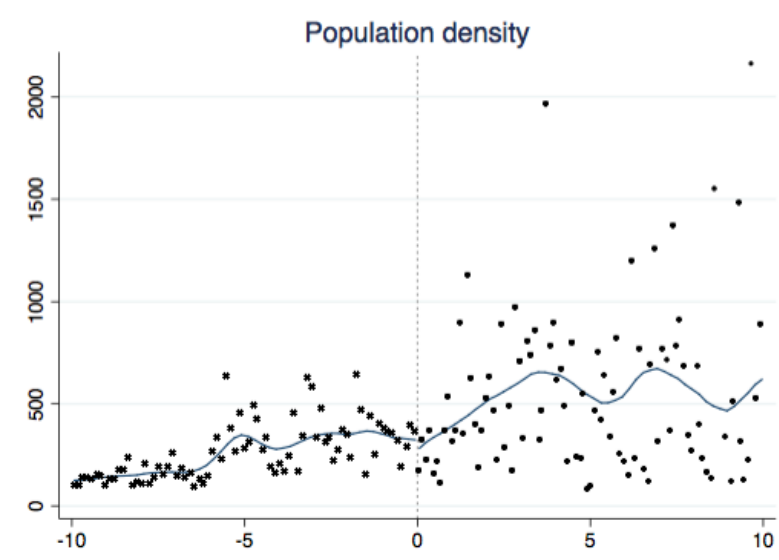

(c) Population density

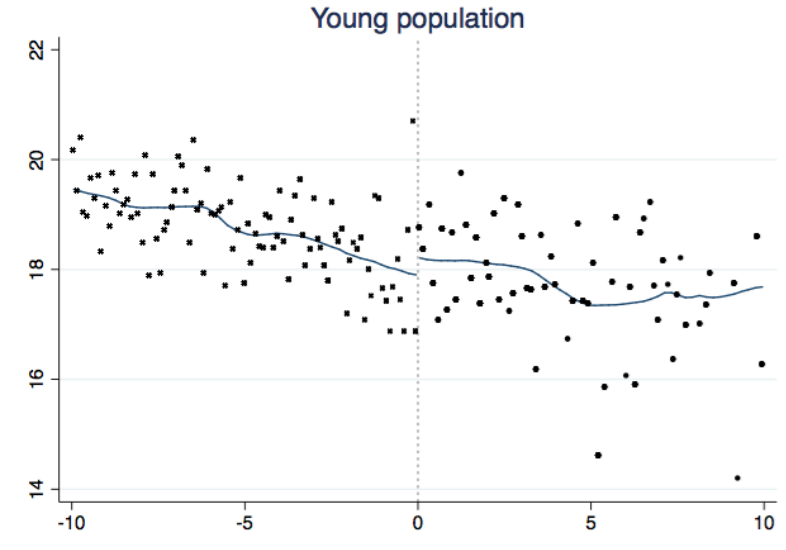

(b) Young population

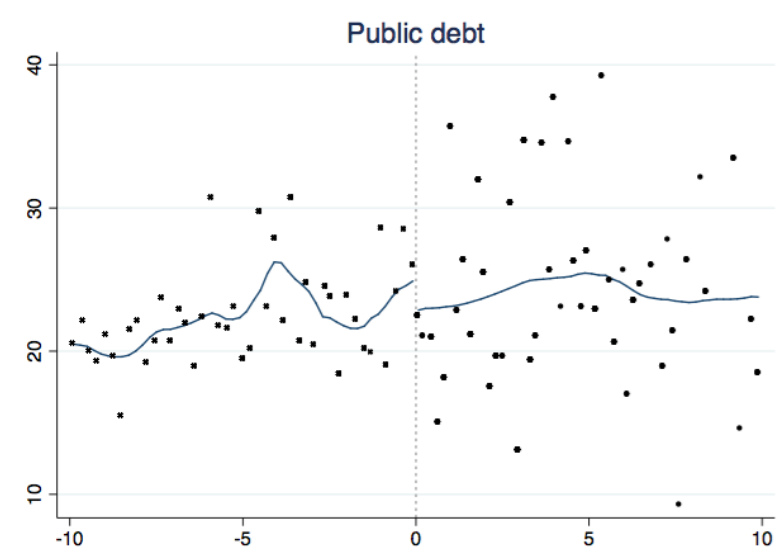

(d) Public debt 


\section{Appendix C. Additional Tests of the Main Results}

Table C.12: Grants dependent on the margin of victory/loss of an aligned candidate - half of the optimal bandwidth

\begin{tabular}{|c|c|c|c|}
\hline & $(1)$ & $(2)$ & (3) \\
\hline \multirow[t]{2}{*}{ RD Estimate } & $0.068^{* * *}$ & $0.121^{* * *}$ & $0.167^{* * *}$ \\
\hline & {$[0.021]$} & {$[0.027]$} & {$[0.032]$} \\
\hline Robust $95 \%$ CI & {$[.115 ; .232]$} & {$[.147 ; .286]$} & {$[.155 ; .309]$} \\
\hline Kernel Type & Triangular & Triangular & Triangular \\
\hline BW Type & $1 / 2 \mathrm{CCT}$ & $1 / 2 \mathrm{CCT}$ & $1 / 2 \mathrm{CCT}$ \\
\hline Eff. Observations L & 683 & 834 & 1014 \\
\hline Eff. Observations R & 725 & 916 & 1215 \\
\hline Conventional p-value & 0.001 & 0.000 & 0.000 \\
\hline Robust p-value & 0.000 & 0.000 & 0.000 \\
\hline Order Loc. Poly. (p) & 1 & 2 & 3 \\
\hline Order Bias (q) & 2 & 3 & 4 \\
\hline BW Loc. Poly. (h) & 5.856 & 7.143 & 8.655 \\
\hline BW Bias (b) & 5.856 & 7.143 & 8.655 \\
\hline
\end{tabular}


Table C.13: Grants dependent on the margin of victory/loss of an aligned candidate - three halves of the optimal bandwidth

\begin{tabular}{lccc}
\hline \hline & $(1)$ & $(2)$ & $(3)$ \\
\hline RD Estimate & 0.002 & $0.039^{* *}$ & $0.077^{* * *}$ \\
& {$[0.010]$} & {$[0.015]$} & {$[0.018]$} \\
\hline Robust 95\% CI & {$[.032 ; .095]$} & {$[.054 ; .131]$} & {$[.059 ; .147]$} \\
Kernel Type & Triangular & Triangular & Triangular \\
BW Type & $3 / 2$ CCT & $3 / 2$ CCT & $3 / 2$ CCT \\
Eff. Observations L & 2137 & 2589 & 3190 \\
Eff. Observations R & 2700 & 3150 & 3718 \\
Conventional p-value & 0.871 & 0.008 & 0.000 \\
Robust p-value & 0.000 & 0.000 & 0.000 \\
Order Loc. Poly. $(\mathrm{p})$ & 1 & 2 & 3 \\
Order Bias $(\mathrm{q})$ & 2 & 3 & 4 \\
BW Loc. Poly. $(\mathrm{h})$ & 17.569 & 21.429 & 25.966 \\
BW Bias (b) & 17.569 & 21.429 & 25.966 \\
\hline \hline ＜ $0.1, * * p<0.05, * * *$ & $p<0.01$. Standard errors in brackets.
\end{tabular}

\section{Appendix D. Other Possible Covariates and Channels}

Another possible channel of transmission is the competence or ability of the mayor, which affects the success in applying for grants. Whereas we cannot measure competence directly, we have information about the education of the mayors. As visualized in Table D.14, for the year 2006 (for which data are available), there are no differences in the fractions of mayors with higher education above and below the population thresholds. It seems that education of the mayor is not related to the change in the electoral system. 
Table D.14: Higher education of the mayor -linear (polynomial) probability model in (1)-(4), categorical outcomes model of $\mathrm{Xu}(2017)$ in (5)

\begin{tabular}{lccccc}
\hline \hline & $(1)$ & $(2)$ & $(3)$ & $(4)$ & 5 \\
& Education & Education & Education & Education & Education \\
\hline RD Estimate & 0.004 & 0.019 & 0.049 & 0.067 & 0.002 \\
& {$[0.104]$} & {$[0.148]$} & {$[0.192]$} & {$[0.234]$} & {$[0.257]$} \\
\hline Robust 95\% CI & {$[-.256, .253]$} & {$[-.312, .376]$} & {$[-.363, .501]$} & {$[-.462, .588]$} & {$[-0.489,0.520]$} \\
Kernel Type & Triangular & Triangular & Triangular & Triangular & Uniform \\
BW Type & CCT & CCT & CCT & CCT & Xu (2017) \\
Eff. Observations L & 134 & 174 & 197 & 225 & 189 \\
Eff. Observations R & 89 & 103 & 112 & 118 & 107 \\
Conventional p-value & 0.967 & 0.899 & 0.797 & 0.775 & 0.850 \\
Robust p-value & 0.988 & 0.854 & 0.754 & 0.814 & 0.952 \\
Order Loc. Poly. $(\mathrm{p})$ & 1 & 2 & 3 & 4 & 1 \\
Order Bias (q) & 2 & 3 & 4 & 5 & 2 \\
BW Loc. Poly. (h) & 4.184 & 5.057 & 5.835 & 6.332 & 5.487 \\
BW Bias (b) & 6.215 & 6.421 & 6.822 & 6.816 & 4.741 \\
\hline \hline
\end{tabular}

Other potential channels of transmission can be excluded. One possibility is that municipalities below the threshold have different economic characteristics, in particular that they are "poorer", and the central government sees the necessity to provide them with additional funding. This can easily be checked as economic development can be measured by income from personal and corporate income taxation. If we observe no discontinuity in these variables, we can safely assume that the municipalities have similar characteristics. Table D.15 shows the differences in discontinuities in the income from personal and corporate taxation. This table shows that the results are not driven by the differences in these incomes. 
Table D.15: (log) income from personal and corporate taxation per capita: local linear regression, bandwidth $=2,000$ (Columns 1 and 2), according to CCT (Columns 3 and 4) and 5,000 (Columns 5 and 6) with time and province fixed effects

\begin{tabular}{lcccccc}
\hline \hline & $(1)$ & $(2)$ & $(3)$ & $(4)$ & $(5)$ & $(6)$ \\
& $\mathrm{h}=2000$ & $\mathrm{~h}=2000$ & $\mathrm{~h}=2809$ & $\mathrm{~h}=2809$ & $\mathrm{~h}=5000$ & $\mathrm{~h}=5000$ \\
\hline Majoritarian Election=1 & $0.30^{* * *}$ & 0.10 & $0.29^{* * *}$ & 0.07 & $0.27^{* * *}$ & 0.08 \\
& $(3.32)$ & $(1.16)$ & $(3.41)$ & $(0.90)$ & $(3.91)$ & $(1.21)$ \\
Direct Mayor=1 & $0.37^{* * *}$ & $0.67^{* * *}$ & $0.38^{* * *}$ & $0.65^{* * *}$ & $0.40^{* * *}$ & $0.73^{* * *}$ \\
& $(4.17)$ & $(9.86)$ & $(5.48)$ & $(11.32)$ & $(8.54)$ & $(18.92)$ \\
Majoritarian Election=1 $\times$ Direct Mayor=1 & 0.16 & 0.15 & 0.13 & $0.14^{*}$ & 0.04 & 0.06 \\
& $(1.10)$ & $(1.34)$ & $(1.24)$ & $(1.77)$ & $(0.51)$ & $(1.04)$ \\
Constant & $4.19^{* * *}$ & $4.09^{* * *}$ & $4.18^{* * *}$ & $4.15^{* * *}$ & $4.24^{* * *}$ & $4.17^{* * *}$ \\
& $(53.23)$ & $(40.45)$ & $(54.50)$ & $(46.26)$ & $(68.45)$ & $(57.48)$ \\
\hline Observations & 959 & 959 & 1471 & 1471 & 2882 & 2882 \\
\hline \hline Time effects & NO & YES & NO & YES & NO & YES \\
Province effects & NO & YES & NO & YES & NO & YES \\
\hline \hline
\end{tabular}

Local linear regression specification as in Equation 1; robust standard errors clustered at municipality level; t-statistics in brackets; p $0.01 * * * 0.05 * * 0.1 *$; not reported: time and province effects, population polynomials, interaction of population and treatment variables.

Finally, one could imagine that extensive migration from Poland after it joined the European Union in 2004 (particularly to the United Kingdom) might have affected the economic development of municipalities. Although we do not see an obvious reason why migration would differentially affect municipalities above or below the threshold, we can check this directly. Table D.16 shows regressions with yearly net migration (expressed as $\left.\Delta p o p / p o p_{t-1}\right)$. This allows us to exclude the possibility that the changes in property taxation were occurring at the extensive margin, i.e., through an increase/decrease in the tax base via migratory movements. According to Table D.16, this is not the case. 
Table D.16: (Net migration: local linear regression, bandwidth=2,000 (Columns 1 and 2), according to CCT (Columns 3 and 4) and 5,000 (Columns 5 and 6) with time and province fixed effects

\begin{tabular}{lcccccc}
\hline \hline & $(1)$ & $(2)$ & $(3)$ & $(4)$ & $(5)$ & $(6)$ \\
& $\mathrm{h}=2000$ & $\mathrm{~h}=2000$ & $\mathrm{~h}=1505$ & $\mathrm{~h}=1505$ & $\mathrm{~h}=5000$ & $\mathrm{~h}=5000$ \\
\hline Majoritarian Election=1 & 0.06 & -0.04 & 0.30 & 0.16 & -0.08 & $-0.22^{* *}$ \\
& $(0.42)$ & $(-0.35)$ & $(1.46)$ & $(0.96)$ & $(-0.91)$ & $(-2.33)$ \\
Direct Mayor=1 & -0.19 & 0.06 & -0.01 & 0.18 & $-0.15^{*}$ & -0.04 \\
& $(-1.57)$ & $(0.53)$ & $(-0.09)$ & $(1.07)$ & $(-1.73)$ & $(-0.49)$ \\
Majoritarian Election=1 Direct Mayor=1 & 0.30 & $0.32^{*}$ & 0.14 & 0.18 & 0.18 & 0.17 \\
& $(1.59)$ & $(1.73)$ & $(0.52)$ & $(0.72)$ & $(1.55)$ & $(1.51)$ \\
Constant & 0.01 & -0.04 & -0.20 & -0.16 & 0.07 & 0.14 \\
& $(0.07)$ & $(-0.27)$ & $(-1.34)$ & $(-0.64)$ & $(0.81)$ & $(1.04)$ \\
\hline Observations & 954 & 954 & 683 & 683 & 2885 & 2885 \\
\hline \hline Time effects & NO & YES & NO & YES & NO & YES \\
Province effects & NO & YES & NO & YES & NO & YES \\
\hline \hline
\end{tabular}

Local linear regression specification as in Equation 1; robust standard errors clustered at municipality level; t-statistics in brackets; p $0.01 * * * 0.05 * * 0.1 *$; not reported: time and province effects, population polynomials, interaction of population and treatment variables.

\section{Appendix E. Robustness of the Specifications}

It could be a matter of concern that in the case of a long time period, the regression analysis picks up a larger number of confounding factors leading to biased results. Although we control for time effects in our main regression, we wish to ensure that unobservable timedependent factors do not drive the results. For instance, starting in 2008, an economic crisis hit Europe and might have caused changes in the revenues from taxation. Although Poland did not experience a recession, we need to make sure that this one-of-a-kind economic shock did not have differential effects on the analyzed municipalities.

As a first robustness check, we therefore demonstrate that our results are stable if we consider a different (narrower) time span. Since we have access to data for only one electoral term before the 2002 reform, for balance, we also consider only one electoral term 
after the reform. Thus, we run a similar model to that in the main specification, but only for the time period 1998-2006. Table E.17 (for property tax income), Table E.18 (for intergovernmental grants) and Table E.19 (for vertical fiscal imbalance) present the results. As can be seen, all results appear to be largely confirmed. We still observe a significant joint effect of the majoritarian system combined with direct election of the mayor, on the incomes from property taxes, grants and the vertical fiscal imbalance, except for the specification in column (6), for which the coefficient is no longer significant.

Table E.17: Property tax up to 2006: local linear regression, bandwidth=2,000 (Columns 1 and 2), according to CCT (Columns 3 and 4) and 5,000 (Columns 5 and 6) with time and province fixed effects

\begin{tabular}{lcccccc}
\hline \hline & $(1)$ & $(2)$ & $(3)$ & $(4)$ & $(5)$ & $(6)$ \\
& $\mathrm{h}=2000$ & $\mathrm{~h}=2000$ & $\mathrm{~h}=2069$ & $\mathrm{~h}=2069$ & $\mathrm{~h}=5000$ & $\mathrm{~h}=5000$ \\
\hline Majoritarian Election=1 & -0.01 & -0.00 & -0.06 & -0.04 & 0.03 & 0.02 \\
& $(-0.12)$ & $(-0.06)$ & $(-0.76)$ & $(-0.48)$ & $(0.41)$ & $(0.46)$ \\
Direct Mayor=1 & $0.42^{* * *}$ & $0.15^{*}$ & $0.36^{* * *}$ & 0.12 & $0.42^{* * *}$ & $0.18^{* * *}$ \\
& $(4.81)$ & $(1.67)$ & $(4.02)$ & $(1.29)$ & $(6.37)$ & $(2.82)$ \\
Majoritarian Election=1 Direct Mayor=1 & $0.31^{* * *}$ & $0.17^{*}$ & $0.39^{* * *}$ & $0.21^{* *}$ & $0.15^{*}$ & 0.05 \\
& $(2.67)$ & $(1.67)$ & $(3.28)$ & $(2.10)$ & $(1.77)$ & $(0.66)$ \\
Constant & $4.97^{* * *}$ & $5.42^{* * *}$ & $5.00^{* * *}$ & $5.40^{* * *}$ & $4.99^{* * *}$ & $5.55^{* * *}$ \\
& $(72.18)$ & $(62.04)$ & $(70.83)$ & $(62.56)$ & $(96.59)$ & $(97.44)$ \\
\hline Observations & 848 & 848 & 891 & 891 & 2433 & 2433 \\
\hline \hline Time effects & NO & YES & NO & YES & NO & YES \\
Province effects & NO & YES & NO & YES & NO & YES \\
\hline \hline
\end{tabular}

Local linear regression specification as in Equation 1; robust standard errors clustered at municipality level;

t-statistics in brackets; p $0.01 * * * 0.05 * * 0.1 *$; not reported: time and province effects, population polynomials, interaction of population and treatment variables. 
Table E.18: Grants up to 2006: local linear regression, bandwidth=2,000 (Columns 1 and 2), according to CCT (Columns 3 and 4) and 5,000 (Columns 5 and 6) with time and province fixed effects

\begin{tabular}{lcccccc}
\hline \hline & $(1)$ & $(2)$ & $(3)$ & $(4)$ & $(5)$ & $(6)$ \\
& $\mathrm{h}=2000$ & $\mathrm{~h}=2000$ & $\mathrm{~h}=2234$ & $\mathrm{~h}=2234$ & $\mathrm{~h}=5000$ & $\mathrm{~h}=5000$ \\
\hline Majoritarian Election=1 & $-0.09^{* *}$ & 0.03 & $-0.08^{* *}$ & 0.01 & $-0.12^{* * *}$ & -0.02 \\
& $(-2.27)$ & $(0.75)$ & $(-2.07)$ & $(0.22)$ & $(-4.10)$ & $(-0.62)$ \\
Direct Mayor=1 & $0.14^{* * *}$ & $0.13^{* * *}$ & $0.16^{* * *}$ & $0.13^{* * *}$ & $0.12^{* * *}$ & $0.09^{* * *}$ \\
& $(3.21)$ & $(3.06)$ & $(3.76)$ & $(3.09)$ & $(3.59)$ & $(2.81)$ \\
Majoritarian Election=1 Direct Mayor=1 $=1$ & $-0.14^{* *}$ & $-0.15^{* * *}$ & $-0.15^{* * *}$ & $-0.14^{* * *}$ & -0.02 & $-0.06^{*}$ \\
& $(-2.50)$ & $(-3.14)$ & $(-2.68)$ & $(-2.99)$ & $(-0.45)$ & $(-1.83)$ \\
Constant & $5.68^{* * *}$ & $5.59^{* * *}$ & $5.67^{* * *}$ & $5.62^{* * *}$ & $5.69^{* * *}$ & $5.61^{* * *}$ \\
& $(164.90)$ & $(135.94)$ & $(170.83)$ & $(143.74)$ & $(221.59)$ & $(197.46)$ \\
\hline Observations & 848 & 848 & 968 & 968 & 2433 & 2433 \\
\hline \hline Time effects & NO & YES & NO & YES & NO & YES \\
Province effects & NO & YES & NO & YES & NO & YES \\
\hline \hline
\end{tabular}

Local linear regression specification as in Equation 1; robust standard errors clustered at municipality level; t-statistics in brackets; p $0.01 * * * 0.05 * * 0.1 *$; not reported: time and province effects, population polynomials, interaction of population and treatment variables. 
Table E.19: Vertical fiscal imbalance up to 2006: local linear regression, bandwidth=2,000 (Columns 1 and 2), according to CCT (Columns 3 and 4) and 5,000 (Columns 5 and 6) with time and province fixed effects

\begin{tabular}{lcccccc}
\hline \hline & $(1)$ & $(2)$ & $(3)$ & $(4)$ & $(5)$ & $(6)$ \\
& $\mathrm{h}=2000$ & $\mathrm{~h}=2000$ & $\mathrm{~h}=2518$ & $\mathrm{~h}=2518$ & $\mathrm{~h}=5000$ & $\mathrm{~h}=5000$ \\
\hline Majoritarian Election=1 & 0.02 & -0.02 & 0.03 & -0.03 & $0.03^{*}$ & 0.01 \\
& $(0.70)$ & $(-1.08)$ & $(1.19)$ & $(-1.57)$ & $(1.85)$ & $(0.46)$ \\
Direct Mayor=1 & 0.02 & 0.01 & 0.02 & 0.01 & 0.00 & -0.00 \\
& $(0.82)$ & $(0.32)$ & $(1.07)$ & $(0.31)$ & $(0.25)$ & $(-0.09)$ \\
Majoritarian Election=1 Direct Mayor=1 & $-0.15^{* * *}$ & $-0.06^{* *}$ & $-0.13^{* * *}$ & -0.04 & $-0.10^{* * *}$ & $-0.04^{* *}$ \\
& $(-4.73)$ & $(-2.13)$ & $(-4.53)$ & $(-1.56)$ & $(-4.63)$ & $(-2.06)$ \\
Constant & $0.57^{* * *}$ & $0.54^{* * *}$ & $0.56^{* * *}$ & $0.53^{* * *}$ & $0.56^{* * *}$ & $0.50^{* * *}$ \\
& $(30.81)$ & $(23.50)$ & $(31.73)$ & $(25.58)$ & $(42.05)$ & $(34.71)$ \\
\hline Observations & 840 & 840 & 1092 & 1092 & 2419 & 2419 \\
\hline \hline Time effects & NO & YES & NO & YES & NO & YES \\
Province effects & NO & YES & NO & YES & NO & YES \\
\hline \hline
\end{tabular}

Local linear regression specification as in Equation 1; robust standard errors clustered at municipality level; t-statistics in brackets; p $0.01 * * * 0.05 * * 0.1 *$; not reported: time and province effects, population polynomials, interaction of population and treatment variables.

Another robustness check is performed by excluding municipalities that crossed the threshold in the analyzed period. This involves a total of six changes, and thus 97 observations. Results are presented in Tables E.20, E.21 and E.22, and remain in line with the main specifications. 
Table E.20: Property tax without municipalities that crossed the threshold:local linear regression, bandwidth $=2,000$ (Columns 1 and 2), according to CCT (Columns 3 and 4) and 5,000 (Columns 5 and 6) with time and province fixed effects

\begin{tabular}{lcccccc}
\hline \hline & $(1)$ & $(2)$ & $(3)$ & $(4)$ & $(5)$ & $(6)$ \\
& $\mathrm{h}=2000$ & $\mathrm{~h}=2000$ & $\mathrm{~h}=2119$ & $\mathrm{~h}=2119$ & $\mathrm{~h}=5000$ & $\mathrm{~h}=5000$ \\
\hline Majoritarian Election=1 & -0.00 & -0.05 & -0.06 & -0.09 & 0.03 & 0.02 \\
& $(-0.04)$ & $(-0.67)$ & $(-0.68)$ & $(-1.09)$ & $(0.51)$ & $(0.28)$ \\
Direct Mayor=1 & $0.48^{* * *}$ & $0.27^{* * *}$ & $0.42^{* * *}$ & $0.24^{* *}$ & $0.49^{* * *}$ & $0.31^{* * *}$ \\
& $(5.46)$ & $(2.82)$ & $(4.67)$ & $(2.50)$ & $(7.50)$ & $(4.84)$ \\
Majoritarian Election=1 Direct Mayor=1 & $0.38^{* * *}$ & $0.27^{* * *}$ & $0.44^{* * *}$ & $0.31^{* * *}$ & $0.16^{*}$ & 0.05 \\
& $(3.29)$ & $(2.62)$ & $(3.73)$ & $(2.99)$ & $(1.93)$ & $(0.66)$ \\
Constant & $4.95^{* * *}$ & $5.45^{* * *}$ & $4.98^{* * *}$ & $5.44^{* * *}$ & $4.98^{* * *}$ & $5.56^{* * *}$ \\
& $(68.59)$ & $(62.09)$ & $(67.52)$ & $(62.91)$ & $(93.58)$ & $(97.58)$ \\
\hline Observations & 967 & 967 & 1036 & 1036 & 2902 & 2902 \\
\hline \hline Time effects & NO & YES & NO & YES & NO & YES \\
Province effects & NO & YES & NO & YES & NO & YES \\
\hline \hline
\end{tabular}

Local linear regression specification as in Equation 1; robust standard errors clustered at municipality level; t-statistics in brackets; p $0.01 * * * 0.05 * * 0.1 *$; not reported: time and province effects, population polynomials, interaction of population and treatment variables. 
Table E.21: Grants without municipalities that crossed the threshold: local linear regression, bandwidth $=2,000$ (Columns 1 and 2), according to CCT (Columns 3 and 4) and 5,000 (Columns 5 and 6) with time and province fixed effects

\begin{tabular}{lcccccc}
\hline \hline & $(1)$ & $(2)$ & $(3)$ & $(4)$ & $(5)$ & $(6)$ \\
& $\mathrm{h}=2000$ & $\mathrm{~h}=2000$ & $\mathrm{~h}=1964$ & $\mathrm{~h}=1964$ & $\mathrm{~h}=5000$ & $\mathrm{~h}=5000$ \\
\hline Majoritarian Election=1 & $-0.14^{* * *}$ & 0.02 & $-0.13^{* * *}$ & 0.02 & $-0.15^{* * *}$ & -0.02 \\
& $(-3.02)$ & $(0.56)$ & $(-2.74)$ & $(0.57)$ & $(-4.43)$ & $(-0.79)$ \\
Direct Mayor=1 & $0.15^{* * *}$ & $0.26^{* * *}$ & $0.15^{* * *}$ & $0.26^{* * *}$ & $0.13^{* * *}$ & $0.20^{* * *}$ \\
& $(3.40)$ & $(5.78)$ & $(3.24)$ & $(5.65)$ & $(3.85)$ & $(6.06)$ \\
Majoritarian Election=1 Direct Mayor=1 $=1$ & -0.08 & $-0.14^{* * *}$ & -0.07 & $-0.12^{* *}$ & 0.03 & -0.05 \\
& $(-1.29)$ & $(-2.93)$ & $(-1.12)$ & $(-2.43)$ & $(0.61)$ & $(-1.49)$ \\
Constant & $5.70^{* * *}$ & $5.59^{* * *}$ & $5.69^{* * *}$ & $5.59^{* * *}$ & $5.70^{* * *}$ & $5.60^{* * *}$ \\
& $(154.12)$ & $(133.08)$ & $(150.29)$ & $(130.35)$ & $(206.31)$ & $(188.58)$ \\
\hline Observations & 967 & 967 & 937 & 937 & 2902 & 2902 \\
\hline \hline Time effects & NO & YES & NO & YES & NO & YES \\
Province effects & NO & YES & NO & YES & NO & YES \\
\hline \hline
\end{tabular}

Local linear regression specification as in Equation 1; robust standard errors clustered at municipality level; t-statistics in brackets; p $0.01 * * * 0.05 * * 0.1 *$; not reported: time and province effects, population polynomials, interaction of population and treatment variables. 
Table E.22: VFI without municipalities that crossed the threshold: local linear regression, bandwidth=2,000 (Columns 1 and 2), according to CCT (Columns 3 and 4) and 5,000 (Columns 5 and 6) with time and province fixed effects

\begin{tabular}{lcccccc}
\hline \hline & $(1)$ & $(2)$ & $(3)$ & $(4)$ & $(5)$ & $(6)$ \\
& $\mathrm{h}=2000$ & $\mathrm{~h}=2000$ & $\mathrm{~h}=2218$ & $\mathrm{~h}=2218$ & $\mathrm{~h}=5000$ & $\mathrm{~h}=5000$ \\
\hline Majoritarian Election=1 & 0.01 & -0.01 & 0.02 & -0.01 & $0.03^{*}$ & 0.01 \\
& $(0.42)$ & $(-0.69)$ & $(0.82)$ & $(-0.70)$ & $(1.65)$ & $(0.54)$ \\
Direct Mayor=1 & 0.01 & 0.02 & 0.02 & 0.02 & -0.01 & -0.01 \\
& $(0.46)$ & $(0.63)$ & $(0.82)$ & $(0.89)$ & $(-0.43)$ & $(-0.44)$ \\
Majoritarian Election=1 Direct Mayor=1 & $-0.14^{* * *}$ & $-0.07^{* *}$ & $-0.14^{* * *}$ & $-0.06^{* *}$ & $-0.09^{* * *}$ & $-0.04^{* *}$ \\
& $(-4.59)$ & $(-2.48)$ & $(-4.56)$ & $(-2.15)$ & $(-4.42)$ & $(-2.03)$ \\
Constant & $0.58^{* * *}$ & $0.54^{* * *}$ & $0.58^{* * *}$ & $0.54^{* * *}$ & $0.57^{* * *}$ & $0.50^{* * *}$ \\
& $(29.97)$ & $(23.18)$ & $(30.03)$ & $(24.05)$ & $(40.95)$ & $(33.85)$ \\
\hline Observations & 959 & 959 & 1090 & 1090 & 2882 & 2882 \\
\hline \hline Time effects & NO & YES & NO & YES & NO & YES \\
Province effects & NO & YES & NO & YES & NO & YES \\
\hline \hline
\end{tabular}

Local linear regression specification as in Equation 1; robust standard errors clustered at municipality level; t-statistics in brackets; p $0.01 * * * 0.05 * * 0.1 *$; not reported: time and province effects, population polynomials, interaction of population and treatment variables.

The falsification tests presented in Figures E.10, E.11 and E.12 show that no discontinuity and no significant interaction effect is observed for the variables of interest at counterfactual thresholds between 18,000 and 22,000, further confirming that the results are credible. 
Figure E.10: Sensitivity around the cutoff: property taxes

(a) Discontinuity

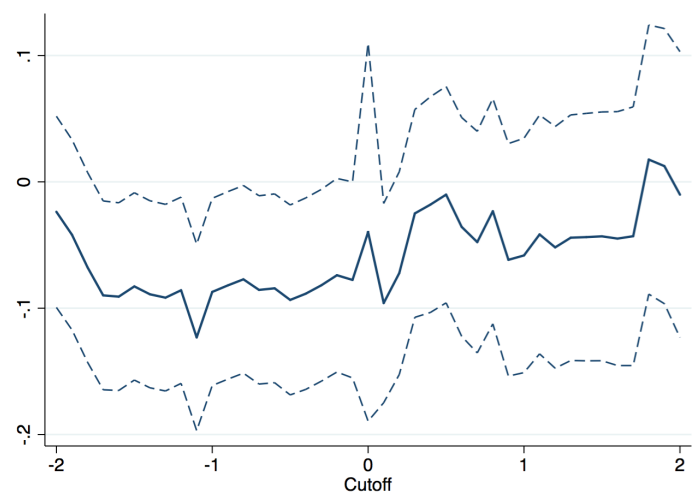

(b) Interaction effect

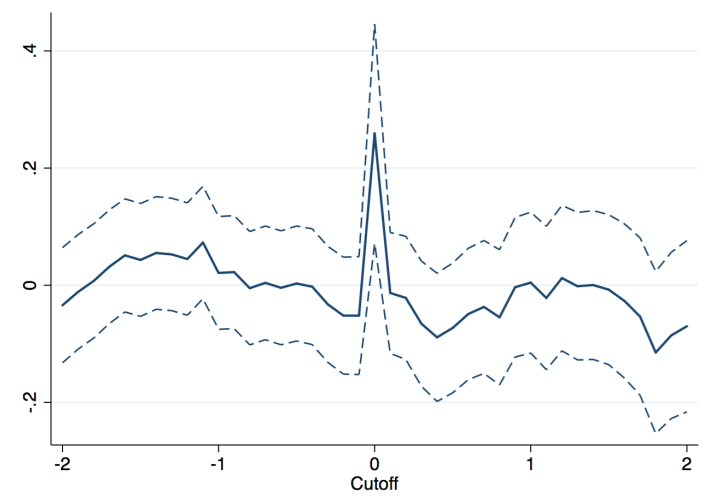

Vertical axis: coefficients; horizontal axis: placebo cutoffs between -2 (18,000 inhabitants) and 2 (22,000 inhabitants). Estimates from the local linear regression specification as in Equation 1 with robust standard errors clustered at municipality level and fixed and year effects, with CCT bandwidths. Dashed lines correspond to the $95 \%$ confidence intervals of the estimates.

Figure E.11: Sensitivity around the cutoff: grants

(a) Discontinuity

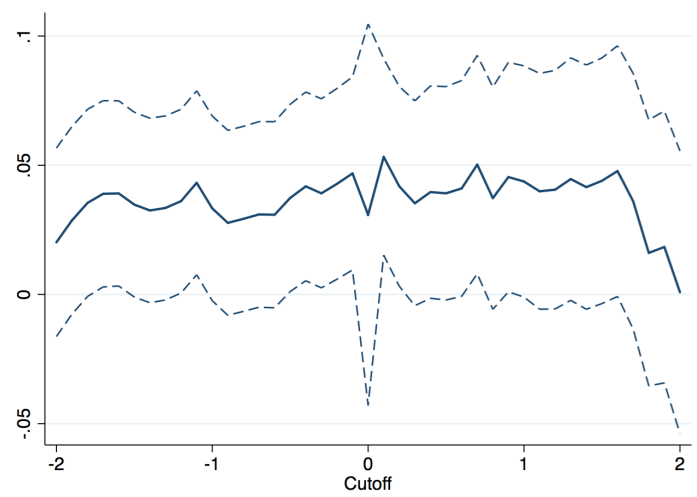

(b) Interaction effect

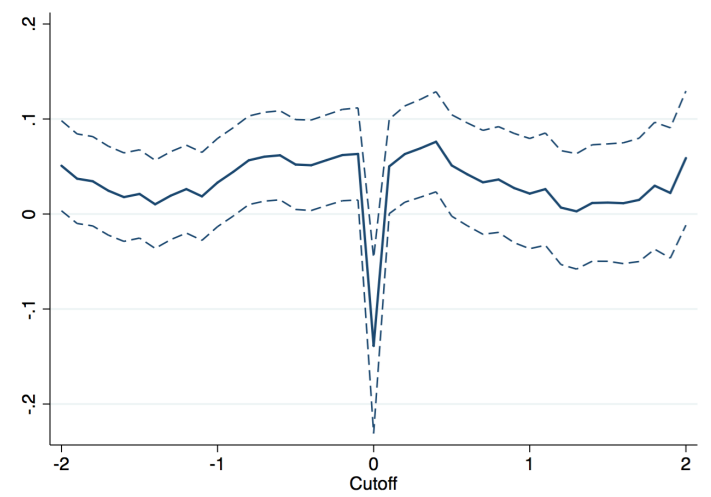

Vertical axis: coefficients; horizontal axis: placebo cutoffs between -2 (18,000 inhabitants) and 2 (22,000 inhabitants). Estimates from the local linear regression specification as in Equation 1 with robust standard errors clustered at municipality level and fixed and year effects, with CCT bandwidths. Dashed lines correspond to the $95 \%$ confidence intervals of the estimates. 
Figure E.12: Sensitivity around the cutoff: VFI

(a) Discontinuity

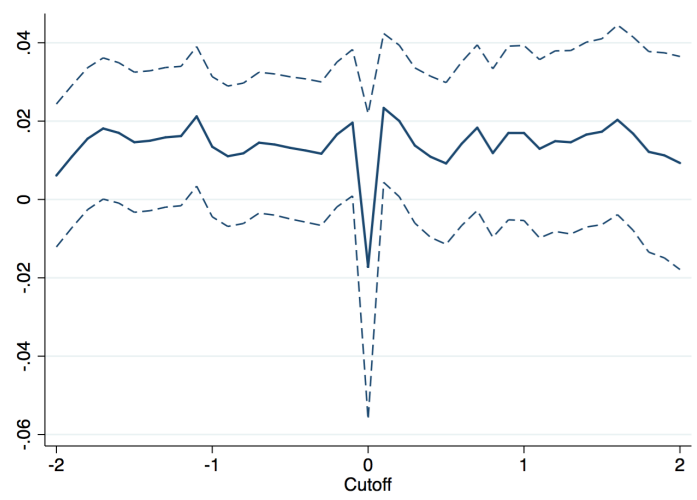

(b) Interaction effect

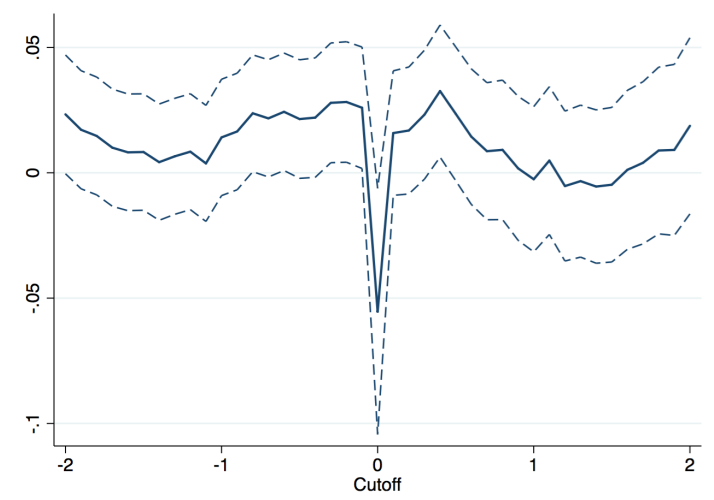

Vertical axis: coefficients; horizontal axis: placebo cutoffs between -2 (18,000 inhabitants) and 2 (22,000 inhabitants). Estimates from the local linear regression specification as in Equation 1 with robust standard errors clustered at municipality level and fixed and year effects, with CCT bandwidths. Dashed lines correspond to the $95 \%$ confidence intervals of the estimates.

Furthermore, to exclude the possibility that differences in property tax income, intergovernmental grants and vertical fiscal imbalance are driven by the council size, we report the effect for population thresholds of 4,000 (demarcating council sizes of 15 and 18 members), 7,000 (demarcating council sizes of 18 and 20 members), 10,000 (demarcating council sizes of 20 and 22 members) and 15,000 (demarcating council sizes of 22 and 24 members) in Tables E.23, E.24 and E.25, respectively. 
Table E.23: Falsification tests - property taxes, cutoff $=4,000 ; 7,000 ; 10,000 ; 15,000:$ LLR, bandwidth=2,000, before the 2002 reform with time and province fixed effects

\begin{tabular}{|c|c|c|c|c|}
\hline & (1) & $(2)$ & (3) & $(4)$ \\
\hline & Property tax pc & Property tax pc & Property tax pc & Property tax pc \\
\hline \multirow[t]{2}{*}{ cut-off $4=1$} & -1.87 & & & \\
\hline & $(-1.45)$ & & & \\
\hline \multirow[t]{2}{*}{ cut-off7 $=1$} & & 0.40 & & \\
\hline & & $(0.52)$ & & \\
\hline \multirow[t]{2}{*}{ cut-off10=1 } & & & $1.35^{*}$ & \\
\hline & & & $(1.93)$ & \\
\hline \multirow[t]{2}{*}{ cut-off15=1 } & & & & 0.52 \\
\hline & & & & $(1.05)$ \\
\hline \multirow[t]{2}{*}{ Constant } & $5.60^{* * *}$ & $5.32^{* * *}$ & $4.87^{* * *}$ & $5.14^{* * *}$ \\
\hline & $(9.39)$ & $(9.43)$ & $(10.36)$ & $(22.39)$ \\
\hline Observations & 5145 & 5594 & 2902 & 1046 \\
\hline
\end{tabular}

Local linear regression specification as in Equation 1; robust standard errors clustered at municipality level;

t-statistics in brackets; p $0.01 * * * 0.05 * * 0.1 *$; not reported: time and province effects, population polynomials, interaction of population and treatment variables. 
Table E.24: Falsification tests - grants, cut-off $=4,000 ; 7,000 ; 10,000 ; 15,000:$ LLR, bandwidth $=2,000$, before the 2002 reform with time and province fixed effects

\begin{tabular}{lcccc}
\hline \hline & $(1)$ & $(2)$ & $(3)$ & $(4)$ \\
& Real grants pc & Real grants pc & Real grants pc & Real grants pc \\
\hline cut-off4=1 & -0.02 & & & \\
& $(-0.05)$ & & & \\
cut-off7 $=1$ & & -0.08 & & \\
cut-off10=1 & & & & \\
& & & & \\
cut-off15=1 & & & & \\
& & & & \\
Constant & $5.95^{* * *}$ & $5.78^{* * *}$ & $5.67^{* * *}$ & -0.22 \\
& $(34.74)$ & $(28.98)$ & $(30.31)$ & $(-1.12)$ \\
\hline Observations & 5143 & 5594 & 2902 & $5.73^{* * *}$ \\
\hline \hline
\end{tabular}

Local linear regression specification as in Equation 1; robust standard errors clustered at municipality level;

t-statistics in brackets; p $0.01 * * * 0.05 * * 0.1 *$; not reported: time and province effects, population polynomials, interaction of population and treatment variables. 
Table E.25: Falsification tests - VFI, cut-off $=4,000 ; 7,000 ; 10,000 ; 15,000$ : LLR, bandwidth=2,000, before the 2002 reform with time and province fixed effects

\begin{tabular}{|c|c|c|c|c|}
\hline & $(1)$ & $(2)$ & (3) & $(4)$ \\
\hline & VFI & VFI & VFI & VFI \\
\hline \multirow[t]{2}{*}{ cut-off $4=1$} & -0.02 & & & \\
\hline & $(-0.08)$ & & & \\
\hline \multirow[t]{2}{*}{ cut-off $7=1$} & & -0.19 & & \\
\hline & & $(-1.38)$ & & \\
\hline \multirow[t]{2}{*}{ cut-off10=1 } & & & -0.14 & \\
\hline & & & $(-0.94)$ & \\
\hline \multirow[t]{2}{*}{ cut-off $15=1$} & & & & -0.21 \\
\hline & & & & $(-1.04)$ \\
\hline \multirow[t]{2}{*}{ Constant } & $0.71^{* * *}$ & $0.72^{* * *}$ & $0.72^{* * *}$ & $0.68^{* * *}$ \\
\hline & $(6.88)$ & $(7.11)$ & $(6.25)$ & $(11.92)$ \\
\hline Observations & 4801 & 5337 & 2805 & 1028 \\
\hline
\end{tabular}

Local linear regression specification as in Equation 1; robust standard errors clustered at municipality level;

t-statistics in brackets; p $0.01 * * * 0.05 * * 0.1 *$; not reported: time and province effects, population polynomials, interaction of population and treatment variables.

Figure E.13 shows the sensitivities of the estimated interaction coefficients to the choice of bandwidth, and further confirms the stability of the results. Above a bandwidth of 1,000 inhabitants, i.e., where a reasonably large sample of observations is available, all coefficients stabilize at the levels reported in the main specifications. 
Figure E.13: Sensitivity of the choice of bandwidth: interaction

(a) Vertical fiscal imbalance

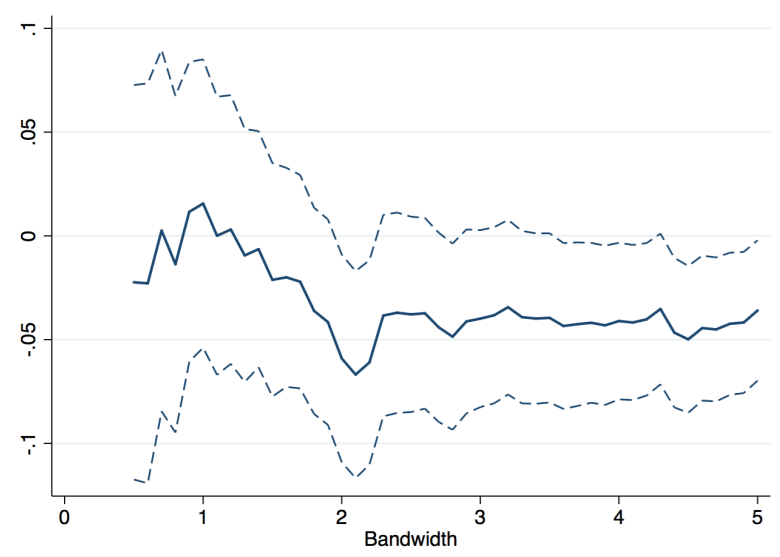

(b) Property tax

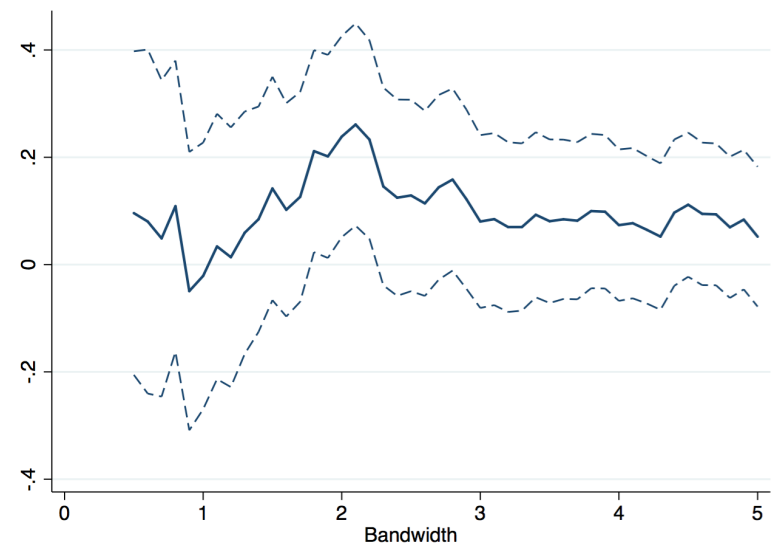

(c) Grants

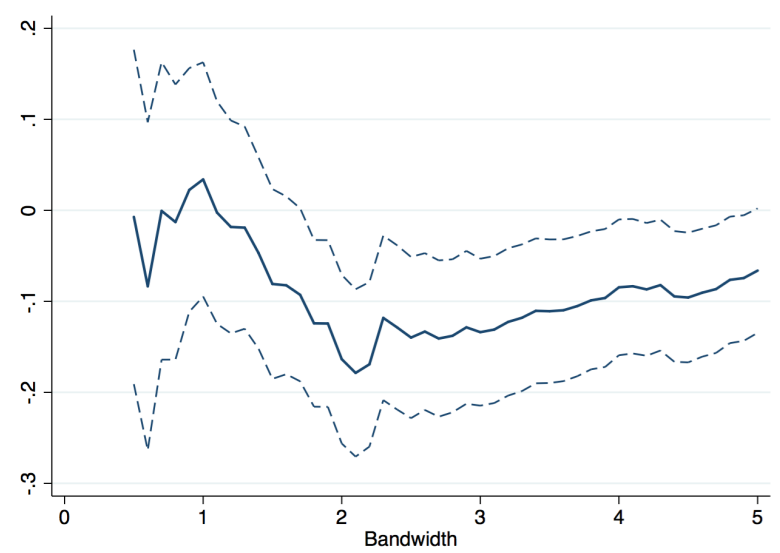

Vertical axis: Coefficients of interaction between the majoritarian system and direct election; horizontal axis: bandwidth (in units of 1,000 inhabitants). Estimates from the local linear regression specification as in Equation 1 with robust standard errors clustered at municipality level and fixed and year effects with varying bandwidths. Dashed lines correspond to the $95 \%$ confidence intervals of the estimates. 